\title{
A Review on Thermoelectric Generators: Progress and Applications
}

\author{
Mohamed Amine Zoui ${ }^{1,2}$ (D), Saïd Bentouba ${ }^{2}$ (D) John G. Stocholm ${ }^{3}$ and Mahmoud Bourouis ${ }^{4, *(D)}$ \\ 1 Laboratory of Energy, Environment and Information Systems (LEESI), University of Adrar, \\ Adrar 01000, Algeria; aminezoui2000@gmail.com \\ 2 Laboratory of Sustainable Development and Computing (LDDI), University of Adrar, Adrar 01000, Algeria; \\ bentouba.said@gmail.com \\ 3 Marvel Thermoelectrics, 11 rue Joachim du Bellay, 78540 Vernouillet, Île de France, France; \\ johngstockholm@gmail.com \\ 4 Department of Mechanical Engineering, Universitat Rovira i Virgili, Av. Països Catalans No. 26, \\ 43007 Tarragona, Spain \\ * Correspondence: mahmoud.bourouis@urv.cat
}

Received: 7 June 2020; Accepted: 7 July 2020; Published: 13 July 2020

\begin{abstract}
A thermoelectric effect is a physical phenomenon consisting of the direct conversion of heat into electrical energy (Seebeck effect) or inversely from electrical current into heat (Peltier effect) without moving mechanical parts. The low efficiency of thermoelectric devices has limited their applications to certain areas, such as refrigeration, heat recovery, power generation and renewable energy. However, for specific applications like space probes, laboratory equipment and medical applications, where cost and efficiency are not as important as availability, reliability and predictability, thermoelectricity offers noteworthy potential. The challenge of making thermoelectricity a future leader in waste heat recovery and renewable energy is intensified by the integration of nanotechnology. In this review, state-of-the-art thermoelectric generators, applications and recent progress are reported. Fundamental knowledge of the thermoelectric effect, basic laws, and parameters affecting the efficiency of conventional and new thermoelectric materials are discussed. The applications of thermoelectricity are grouped into three main domains. The first group deals with the use of heat emitted from a radioisotope to supply electricity to various devices. In this group, space exploration was the only application for which thermoelectricity was successful. In the second group, a natural heat source could prove useful for producing electricity, but as thermoelectricity is still at an initial phase because of low conversion efficiency, applications are still at laboratory level. The third group is progressing at a high speed, mainly because the investigations are funded by governments and/or car manufacturers, with the final aim of reducing vehicle fuel consumption and ultimately mitigating the effect of greenhouse gas emissions.
\end{abstract}

Keywords: thermoelectric generator; figure of merit; thermoelectric materials; nanostructuring

\section{Introduction}

The supply of healthy and non-polluting energy is one of today's major concerns. Fossil fuels currently make up the largest contribution to global energy production. These energy sources are polluting, they emit greenhouse gases and, furthermore, will run out in a few decades' time [1]. The only current competitor is nuclear power, but the fatal risks involved in nuclear operation, as seen in the nuclear accident at the Fukushima Daiichi power plant (Japan) in March 2011, have limited any expansion or development in the nuclear sector [2].

It is essential for future generations to reduce the quantity of global energy consumed, and this can only be achieved through technological development and the use of diversified renewable energy 
sources, i.e., solar, wind and hydropower, in addition to the energy sources currently used [3]. Among these different energy sources, thermoelectricity is currently emerging as a common and promising alternative energy source for the future [4].

Thermoelectric materials have the specific capacity of converting a flow of heat into electrical energy (Seebeck effect) and vice versa (Peltier effect) [5]. Their use is becoming of more interest, as they offer the advantages of recycling waste energy. This means transforming the heat from industry or road transport into electricity, thus increasing system efficiency and decreasing operating costs and environmental pollution. To cite an example of the heat involved, the temperature of exhaust gases emitted from vehicle engines, biomass combustion systems and matrix-stabilized porous medium combustion can reach $500{ }^{\circ} \mathrm{C}$, while the operating temperature of micro-turbine power cycles can rise to $600{ }^{\circ} \mathrm{C}$, and even to $900{ }^{\circ} \mathrm{C}$ in the case of a solar energy receiver [6]. Thermoelectric devices are particularly reliable, silent, and do not generate vibrations since their operation does not require the contribution of mechanical energy [7]. For these reasons, major efforts have been carried out, using new materials, to develop the technology of thermoelectric systems. It was during the 1960s that the most important research programs, using semiconductor materials, were carried out in this field [8].

Since the discovery of thermoelectricity (TE) in 1821 by Seebeck [9], researchers have been trying to understand and control this phenomenon. Peltier did exactly this in 1834 by discovering the opposite effect [10], and Lord Calvin in 1851 formulated the laws that link these two phenomena [11]. In the following century, in 1909, Edmund Altenkirch [12] correctly calculated, for the first time, the energy efficiency of a thermoelectric generator now known as figure of merit (ZT), and two years later that of thermoelectricity in cooling mode [13]. In 1912, Altenkirch invented a thermoelectric heating and cooling apparatus [14], which was later succeeded by several other prototypes developed by various scientists and companies. Unfortunately, these attempts to produce a practical refrigerator failed due to the lack of suitable materials [15]. It is worth note that a ZT $>3$ for refrigeration and ZT $>2$ for power generation is required to replace a conventional energy system [16].

In 1950, Abram Ioffe discovered the thermoelectric properties of semiconductors [17], which opened up new projections for thermoelectricity with a figure of merit ZT close to 1 . This value was still low, but acceptable enough for some inventors and industrialists to design new applications to be commercialized. One such application was the thermoelectric refrigerator designed by Becket et al. in 1956 [18]. In the same decade the idea of thermoelectric generators emerged, such as Ioffé's thermoelectric lamp in 1957, which fed a radio by recovering the heat released by the lamp.

In 1993, Hicks and Mildred Dresselhaus [19] showed that quantum-well superlattice structures (small dimensions of matter) could affect thermoelectricity by reducing phonon thermal conductivity, and therefore improving the ZT by a factor of 13. As a result, a new era in thermoelectricity was launched and gave rise to an exponential increase in the number of research projects being carried out into thermoelectricity (Figure 1) [20]. 


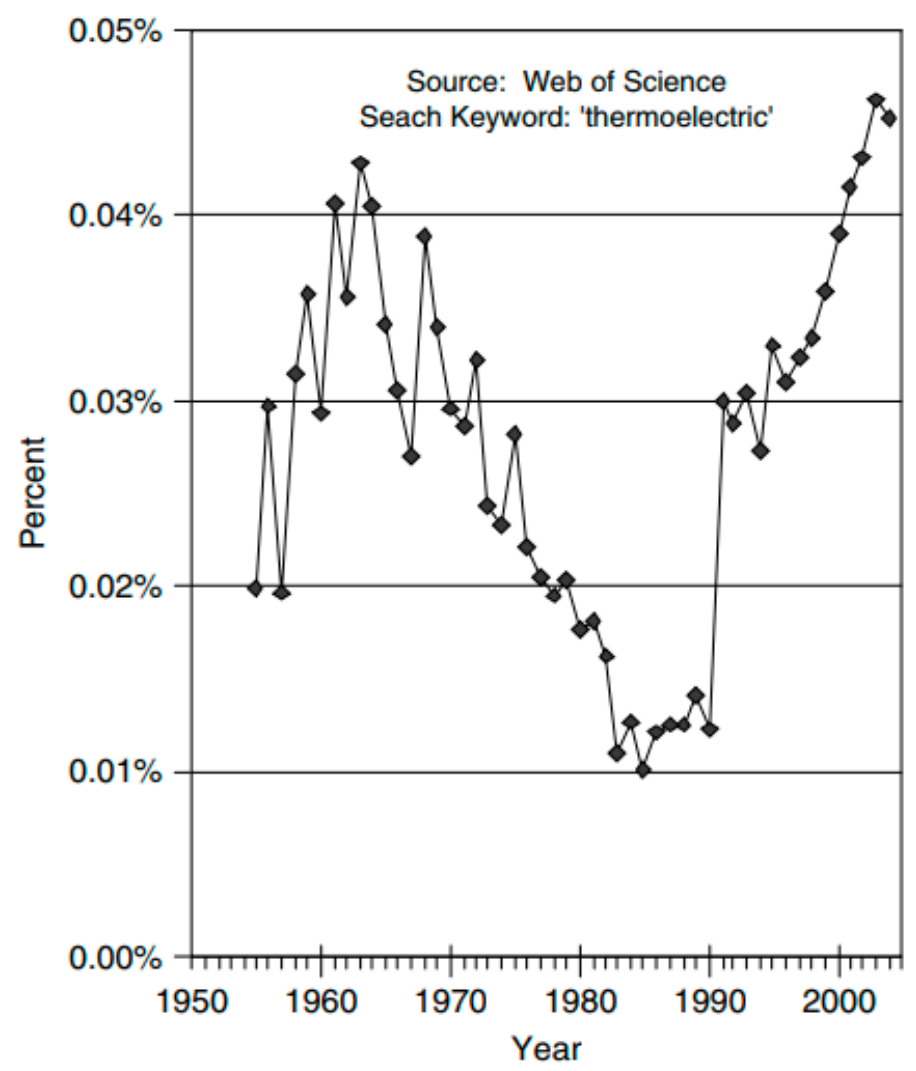

Figure 1. Open literature publications on the Web of Science database with the keyword "thermoelectric" as a percentage of all publications on the database for each year from 1955 to 2003 [20].

\section{Thermoelectric Modules}

To extend the use of thermoelectricity, it was essential to manufacture standard thermoelectric modules of different sizes, accessible to all. In 1959 the General Electric company commercialized [21] thermoelectric modules composed of 36 couples of bismuth telluride in flat bulk architecture. Nowadays, there are dozens of companies all over the world that manufacture TE modules. Some of these are listed in [22].

A typical thermoelectric generator (TEG) module consists of between 10 and 100 thermoelectric elements of type $\mathrm{n}$ and type $\mathrm{p}$, electrically connected in series and thermally in parallel, and interposed between two ceramic layers, as shown in Figure 2. The $\mathrm{p}-\mathrm{n}$ pairs are joined by conductive tabs connected to the elements via a low melting point solder ( $\mathrm{PbSn}$ or $\mathrm{BiSn}$ ). When a temperature gradient occurs between its two junctions, the TEG converts thermal energy into electrical energy according to the principle of the Seebeck effect. This flat bulk architecture is the most widely used and marketed. However, in some applications a flat shape is not practical. This is because of the difficulty in adapting the heat source to the thermoelectric device, which makes it more costly, heavier, and more cumbersome. As a result, other designs are being investigated to overcome these drawbacks, although most of them, like the cylindrical shape [23-25], are still at the laboratory stage. This is the subject of limited studies, unlike thick and thin films and flexible TE devices, which are being developed more effectively [26]. More details on the usefulness of these designs are presented in the following sections.

The two ceramic plates serve as a support for the module and as electrical insulation, but their thermal resistance degrades the module's efficiency. From this, some investigations have proposed the concept of a direct contact thermoelectric generator (DCTEG), which is characterized by one of the surfaces of the module being directly exposed to the heat source and the other surface in direct contact with the coolant flow $[27,28]$. Several manufacturing technologies for TE modules are reported in the literature. Some examples include foil lithography [29], the lift-off process [30], flash evaporation [31], 
evaporation thin film [32], photolithography and etching [33], screen-printing [34], sputtering [35], dispenser printing [36], the spark plasma sintering technique [37], direct current (DC) magnetic sputtering [38] and the printing process [39].

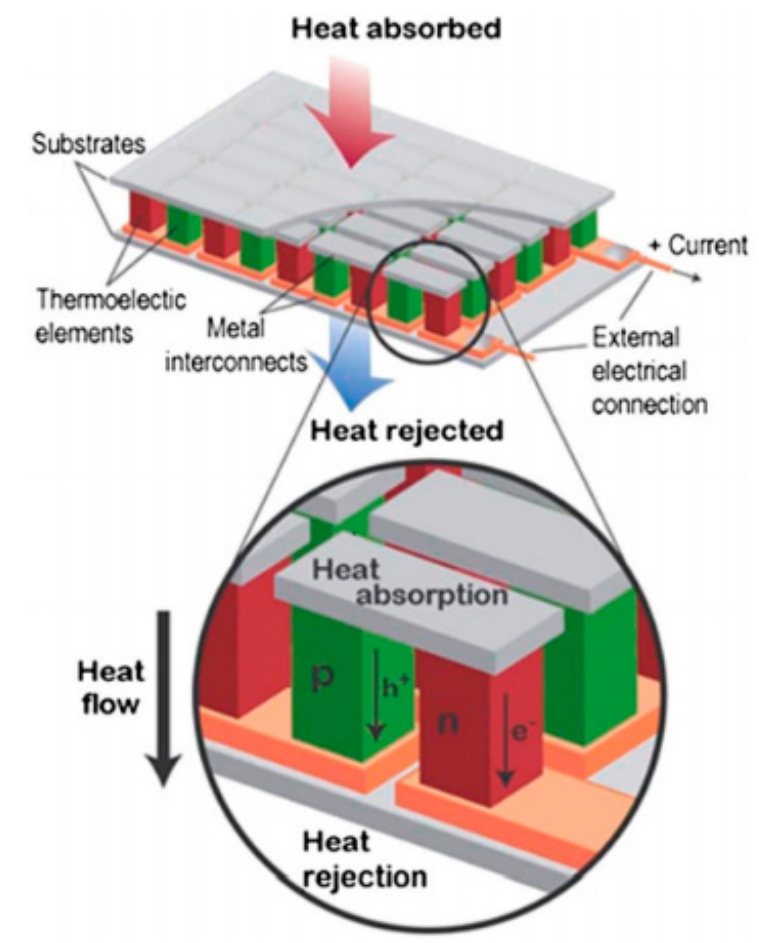

Figure 2. Diagram of a typical thermoelectric device [40].

The critical challenge in the development of TEGs is the degradation of original properties brought on by thermal fatigue, which is in turn caused by thermal expansion and thermal shock [41]. This degradation can be brutal or progressive, and result in a decrease in service life and efficiency. In fact, during the normal operation of TE devices, the shunts are periodically heated and cooled and undergo thermal expansion. The TE materials connected to these shunts can experience different effects of expansion from temperature sources, which cause increased stress at the interface between them. These stresses are generally the main cause of mechanism failure, and consequently the principal reason why TE materials are not sintered and integrated into shunts [42].

\section{Figure of Merit and Other Performance Parameters}

The thermoelectric efficiency of a TE material is expressed by the dimensionless thermoelectric figure of merit $(\mathrm{ZT})$, which is dependent on the transport properties of the material as shown in Equation (1).

$$
\mathrm{ZT}=\frac{S^{2} \sigma \mathrm{T}}{\mathrm{K}}
$$

where $S$ is the Seebeck coefficient $(\mu \mathrm{V} / \mathrm{K}), \sigma$ the electrical conductivity $(1 / \Omega \mathrm{m})$ and $\mathrm{K}$ is the thermal conductivity $(\mathrm{W} / \mathrm{mK})$. This equation shows that, to maximize the $\mathrm{ZT}$ of a material, it must meet the following criteria: (i) low thermal conductivity to maintain a considerable temperature difference between the two ends of the material; (ii) high electrical conductivity to reduce the internal resistance of the material and consequently the Joule effect; and (iii) a high Seebeck coefficient, required to obtain a high voltage [43,44]. Unfortunately, according to the graph of Figure 3, these parameters are well correlated and it is very difficult to optimize them independently, especially for conventional metals. 


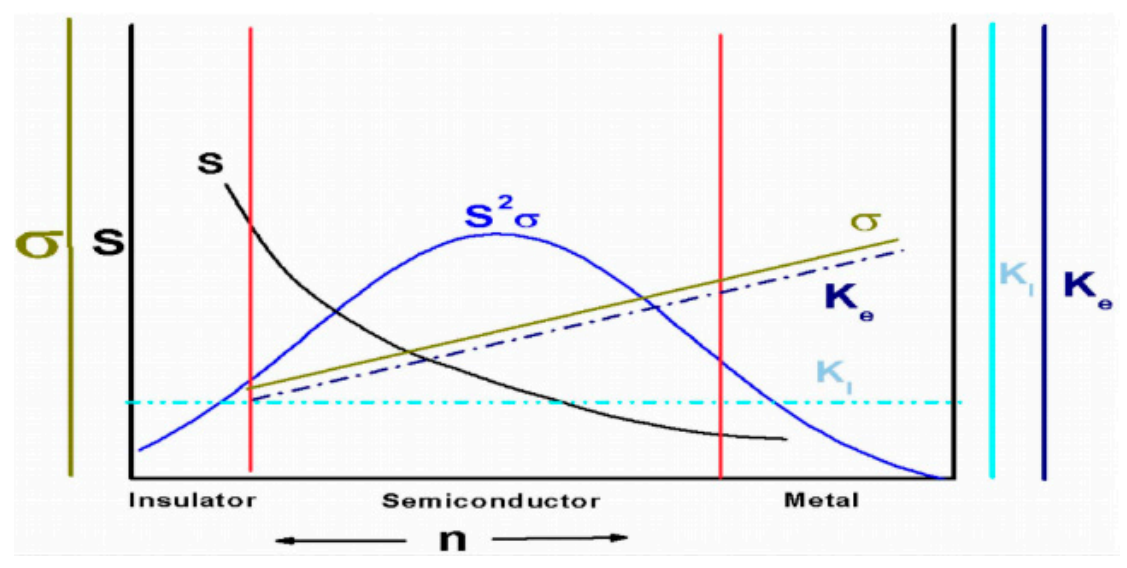

Figure 3. Relationship between figure of merit $\mathrm{ZT}$ and other parameters such as electrical conductivity $\sigma$, Seebeck coefficient $S$, power factor $S^{2} \sigma$, electronic thermal conductivity Ke, thermal conductivity of the network $\mathrm{Kl}$ and total thermal conductivity $\mathrm{K}[16]$.

In the literature, $Z T$ is sometimes referred to as thermoelectric efficiency because it is related to the efficiency of a single element and the device, via Equation (2).

$$
\eta_{\text {opt }}=\frac{\Delta T}{T_{h}} \frac{\sqrt{1+Z T_{\text {ave }}}-1}{\sqrt{1+Z T_{\text {ave }}}+T_{c} / T_{h}}
$$

where $\Delta T$ is the difference between the temperature on the warm side $T_{h}$ and the cold side $T_{c}$. The first term of this equation represents the Carnot efficiency. To determine the efficiency of a thermoelectric generator (TEG), it is necessary to calculate the ratio between the electrical power produced and the heat flow through the module. These basic standard equations are typically built on four main hypotheses, namely (i) the electrical and thermal contact resistances are negligible, (ii) the Thomson effect has a negligible effect on efficiency, (iii) the convection and radiation heat transfer are negligible, and (iv) the dependency on the thermoelectric transport properties of the TEG module with temperature, which makes the performance of TEGs change at different temperatures [45].

There are several ways to calculate the performance of a thermoelectric couple in terms of energy production, either averaging or using finite elements [46,47]. The averaging methods overestimate the efficiency but provide an immediate value based on the calculated properties of the TEG at the average junction temperature [48]. On the other hand, finite elements require a lot of iterations and therefore take more time to obtain results [49].

Although simple one-dimensional analytical models are frequently used to predict the performance of such devices [50], the diversity and complexity of thermoelectric applications generally require a complete three-dimensional (3D) numerical analysis [51], using simulation tools such as ANSYS [52], GT-SUITE [53], FLUENT [54] and GTPower [55].

\section{Thermoelectric Materials}

Ever since the discovery of TE materials, their use has been limited to thermocouples for temperature measurements due to their very low efficiency [56]. It was only in the 1960s when relevant investigations into thermoelectric semiconductors developed more applications in the field of refrigeration and power generation.

From the discovery of thermoelectric semiconductors [17] until 1993, the figure of merit (ZT) experienced a modest improvement. After that date, theoretical predictions suggested that the efficiency of TE materials could be significantly improved by using nanostructure engineering [19]. Rurali et al. [57] theoretically and experimentally explored nanostructuring as effective in reducing the negative correlation of thermoelectric transport properties. For instance, 2D and 1D nanostructuring 
slows down the diffusion of phonons, leading to a decrease in thermal conductivity that in turn increases the efficiency of the TEG. Hence, great interest has arisen in nanostructured thermoelectric materials.

At the same time, using modern synthesis and characterization techniques, conventional bulk materials containing nanostructured components were explored and developed with the aim of achieving higher yields [58]. Thus, nowadays, the ZT factor can be increased in one of two ways: (i) bulk samples containing nanomaterial constitute, and (ii) nanomaterials themselves [59]. It should be mentioned that small (nanostructured) materials are difficult to manufacture with precision due to the high sample requirements on the nanoscale [60]. Thermoelectric materials can be classified into two categories, namely conventional and new materials.

\subsection{Conventional Thermoelectric Materials}

Conventional thermoelectric materials, which are bulk doped semiconductor alloys or chalcogenide, can be grouped into three families according to the temperature range at which the performance is optimum: $\mathrm{Bi}_{2} \mathrm{Te}_{3}$-based materials for ambient temperature applications $\left(<150{ }^{\circ} \mathrm{C}\right)$, TAGS $\left[\left(\mathrm{AgSbTe}_{2}\right) 1-\mathrm{x}(\mathrm{GeTe}) \mathrm{x}\right]$ and $\mathrm{PbTe}$-based materials for intermediate temperature range $\left(150-500^{\circ} \mathrm{C}\right)$, and $\mathrm{SiGe}$ for use at temperatures over $500^{\circ} \mathrm{C}$ [61-63]. The temperature range can be widened by using a combination of materials characterized by different temperature ranges in a segmented structure [64].

$\mathrm{The} \mathrm{Bi}_{2} \mathrm{Te}_{3}$ are well known and can have a $\mathrm{ZT}$ close to the unit at room temperature. However, as they are easily oxidized and vaporized, these materials cannot be used for high-temperature applications in air [65]. Around 70\% of the TE modules available on the market use Bismuth and Telluride as functional materials [66]. Recently, Mamur et al. [67] reviewed the latest research on the growth of the $\mathrm{Bi}_{2} \mathrm{Te}_{3}$ nanostructure by various methods, and its characterization by theoretical and analytical approaches. The authors have concluded that the figure of merit (ZT) rises from 0.58 to 1.16 if materials are developed in a nanostructure form.

Lead telluride $(\mathrm{PbTe})$ is a good thermoelectric material for applications requiring mid-temperatures up to $900 \mathrm{~K}$. PbTe has a high melting point of $1190 \mathrm{~K}$, good chemical stability, low vapor pressure and robust chemical strength [68]. Its high figure of merit, approaching 0.8 , allowed for its successful use in several NASA space missions. Recent investigations have reported maximum ZT values of around 1.4 for single phase PbTe-based materials, and 1.8 for homogeneous PbTe-PbSe materials [69]. An extensive survey of Research and Development on $\mathrm{PbTe}$ and its related compounds, alloys and composites, as well as PbTe-based nanostructured composites, can be found in references [70,71].

Silicon-Germanium alloys $\left(\mathrm{Si}_{1-\mathrm{x}} \mathrm{Ge}_{\mathrm{x}}\right)$ are among the best TE materials reported in the literature for high-temperature applications $\left(T_{\text {hot side }}>500{ }^{\circ} \mathrm{C}\right.$ ). In addition, they are one of the cheapest and most nontoxic thermoelectric materials [61]. Delime-Codrin et al. [72] reported a significant figure of merit, $\mathrm{ZT}=1.88$ at $873 \mathrm{~K}$, with nanostructured $\mathrm{Si}_{0.55} \mathrm{Ge}_{0.35}\left(\mathrm{P}_{0.10} \mathrm{Fe}_{0.01}\right)$.

\subsection{New Thermoelectric Materials}

Phonon-glass electron-crystal (PGEC) materials proposed by Slack [73] have a complex intermetallic cage structure, which gives the material good electronic characteristics like crystal, and at the same time, a low thermal conductivity, like glass [74]. Two categories of relatively new materials are generally considered to be PGEC materials, namely clathrates and Skutterudites [75]. Among other TE materials, half-Heusler alloys have attracted considerable attention with their attractive electrical transport properties, relatively high Seebeck coefficients and rich element combinations [76]. In addition, they boast robust mechanical strength, good thermal stability at high temperatures and multiform physical properties [77]. In 2005, Gascoin et al. [78] proposed phase Zintl as an attractive candidate for thermoelectric materials. These are typically small-bandgap semiconductors with a complex structure. Since then, several studies have been carried out on the use of this type of material, and the best values achieved for ZT ranged from 1 to a peak value of 1.5 [79].

Over the past two decades, since the discovery of the first ceramic thermoelectric material, many efforts have been made to obtain high-performance thermoelectric materials for energy conversion 
systems [80]. TE oxides, such as $\mathrm{Ca}_{3} \mathrm{Co}_{4} \mathrm{O}_{9}(\mathrm{ZT} \sim 1)$, are good TE performers [43], and are ecological and essentially stable at high temperatures [81]. Other oxides that can be used at high temperatures without oxidizing have also attracted much attention in recent years [82].

The thermoelectric metal chalcogenide has high electrical properties and low thermal conductivity, so when advanced nanostructuring and band engineering are employed, the result is an improved figure of merit (ZT). Furthermore, chalcogenides are easy to process into different types of structures, thus offering huge potential for improvement in thermoelectric performance. The highest values of $\mathrm{ZT}$ recorded with lead selenide (PbSe) ranged from 1.4 to 1.7 at $800-900 \mathrm{~K}$ [83]. In the case of Tin chalcogenides $\mathrm{Sn}(\mathrm{Se}, \mathrm{Te})$, numerical values of ZT above 2.3 were obtained at $723-973 \mathrm{~K}$ for single crystal SnSe [84], and about 1.6 at $923 \mathrm{~K}$ for SnTe-based materials [85]. A further advantage is that these materials are low-cost and operate at high and even medium temperatures. However, their low mechanical properties and low thermal stability, and in some cases the presence of toxic elements (e.g., $\mathrm{Pb}$ ), limit their use in real applications.

Since the discovery of conductive polymers, great interest has been shown in organic TE materials [86]. These are lightweight, flexible and suitable for applications at room temperature, generally with relatively simple manufacturing processes compared to other semiconductor-based materials. Polymers are intrinsically poor thermal conductors, which makes them suitable for use in thermoelectricity, but their low electrical conductivity, Seebeck coefficient and stability have limited their use in thermoelectric applications [87]. However, compared to inorganic TE materials, organic or polymeric TE materials boast several advantages, such as a potentially low cost due to the abundance of carbon resources, and a quite simple synthesizing process. In addition, the physical and chemical properties of some polymers can be subjected to a fairly wide range of modifications in their molecular structures [88]. The properties of polymers and polymer-based TE composites have been significantly improved with ZT values up to 0.42 [89]. It is worthy of note that the hybridization method, which consists of mixing all the thermoelectric materials already mentioned, has also achieved results [90].

Another material, Graphene (carbon atoms forming a crystalline two-dimensional material), has attracted considerable interest since its discovery in 2004 because it has many unusual thermoelectric and thermal transport properties [91]. A recent study has reported a thermoelectric figure of merit (ZT) up to 1.4 with graphene and $C_{60}$ clusters synthesized by chemical vapor deposition (CVD) [92]. Another theoretical investigation revealed three peak $\mathrm{ZT}$ values of 2.0, 2.7 and 6.1 at $300 \mathrm{~K}$, with a twisted bilayer graphene nanoribbon junction [93]. As shown in Figure 4, the search for new thermoelectric materials is growing exponentially, but some categories are more attractive than others. 


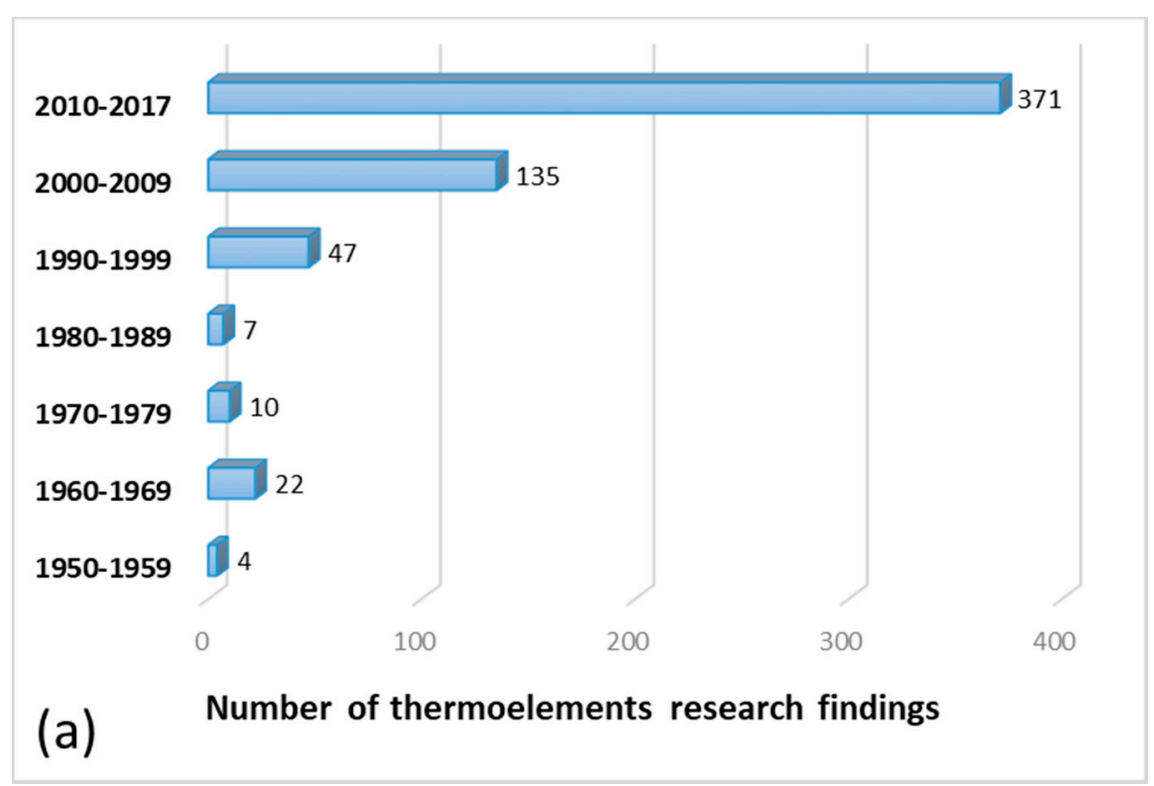

(a)

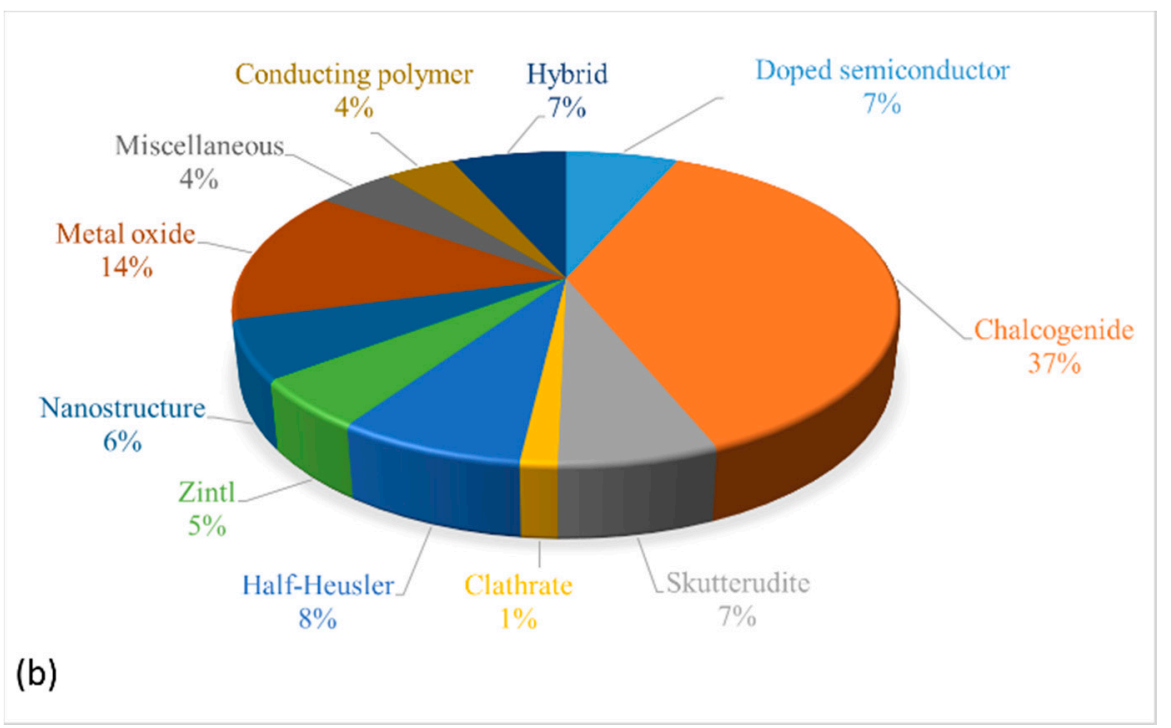

(b)

Figure 4. (a) State of the art thermoelement research findings by year; (b) Development rate in the thermoelements research from 1950 to 2017. Data from [94].

\section{Applications of Thermoelectric Generators}

Thermoelectric applications are classified according to the two effects characterizing the process, namely the Seebeck effect, for any application that generates electricity with a temperature difference, and the Peltier effect for any cooling application powered by an electric current. The latter case is not examined in this article; only applications that generate electricity are presented.

To generate electricity from a TE module, it is necessary for there to be a temperature difference between its hot and cold surfaces. In other words, it is necessary that the heat recovered from the hot source scatters into the semiconductor elements $\mathrm{p}$ and $\mathrm{n}$ of the module, and then to the cold source, which is usually the environment. TEG applications can be classified into three categories, depending on the nature of the hot source: (i) radioisotope heat source, (ii) natural heat source, and (iii) waste heat source. 


\subsection{Radioisotope Heat Source}

A radioisotope thermoelectric generator (RTG) is a nuclear electric generator of simple design. It involves neither a process of fusion nor nuclear fission, which would require significant constraints on the system, but the natural decay of a radioactive atom, usually plutonium 238 in the form of plutonium dioxide $238 \mathrm{PuO}_{2}$. As they disintegrate, radioactive atoms release heat, some of which is directly converted into electricity [95].

The first RTG was developed by Mound Laboratories in 1954 [96]. The heat source consisted of a 1-cm diameter sphere containing $57 \mathrm{Ci}(1.8 \mathrm{Wt})$ of 210Po inside a nickel-coated steel capsule, all in a Lucite container. With silver soldered chromel-constantan Thermocouples, the "thermal battery" produced $1.8 \mathrm{mWe}$ [97]. Three areas, namely the space domain, power supply devices in remote areas, and the medical domain, have benefited from RTGs, although the last two areas have not flourished because of the risks involved in using radioisotopes.

\subsubsection{Space Domain}

The first RTG launched into space by the United States of America was the SNAP 3B in 1961, powered by $96 \mathrm{~g}$ of plutonium metal 238, aboard the Navy Transit 4A spacecraft [98]. In 2010, USA launched 41 RTGs on 26 space systems [99]. Among them were Galileo (launched in 1989 at Jupiter), Ulysses (launched in 1990 as a solar orbital), Cassini (launched in 1997 at Saturn), New Horizons (launched in 2006 to fly over Pluto 2015) and the Curiosity robot from the Mars Science Laboratory (installed on Mars in 2012). Systems for nuclear auxiliary power units (SNAPs) were used for probes that travelled far from the Sun, conditions that make solar panels impractical [100].

The RTGs used in the US space program initially included SiGe TE materials installed in the General Purpose Heat Source-Radioisotope Thermoelectric Generator (GPHS-RTG) GPHS-RTG, later succeeded by the lead telluride alloys, or TAGS, used in multi-mission RTGs (MMRTGs), shown in Figure 5. This MMRTG was developed, under the program called enhanced MMRTG or eMMRTG [101], with the use of new skutterudite thermoelectric materials in order to achieve higher efficiency and lower degradation rates, which are important for long-term missions to the outer planets [102].

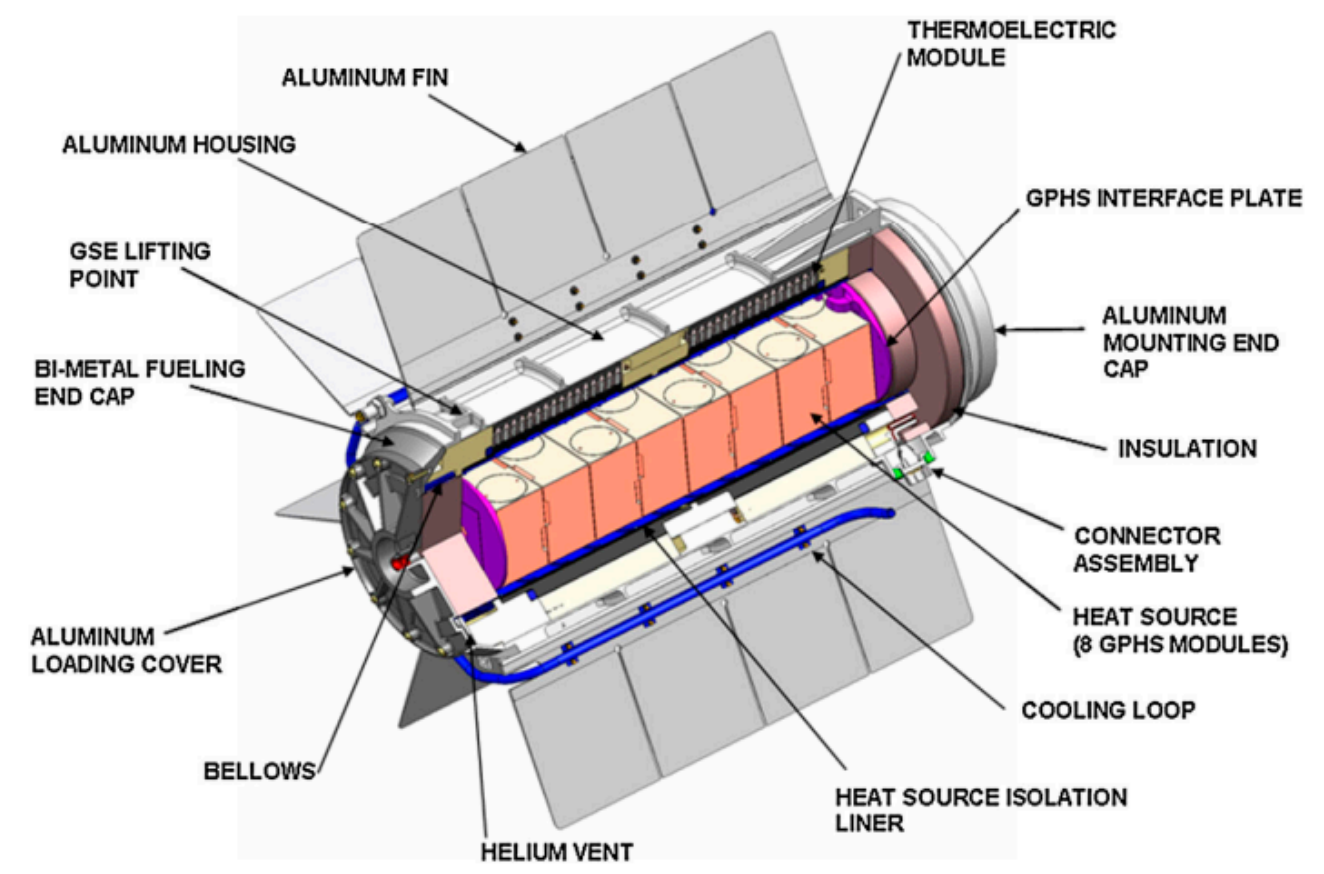

Figure 5. Cutting view of an Multi-Mission Radioisotope Thermoelectric Generator MMRTG [103]. 


\subsubsection{Power Supply Devices in Remote Areas}

One of the first terrestrial uses of RTGs was in 1966 by the U.S. Navy for powering environmental instrumentation at Fairway Rock, a small uninhabited island in Alaska. RTGs were used at this site until 1995 [104]. These systems were developed for the supply of power to equipment requiring a stable and reliable power source, over several years and without maintenance. Examples of these would be power supplies for systems located in isolated or inaccessible environments, like lighthouses, navigation beacons and weather stations. Similarly, between 1960 and 1980, the Soviet Union built many unmanned lighthouses and navigation beacons, equipped with about 1000 RTGs (Figure 6) [105]. All Russian RTGs have long since exhausted their 10-year lifespan, and require extreme dismantling measures due to their status as a potentially dangerous source of radioactivity, and the risk they pose of being used in terrorist acts [106]. Obviously, all research and development in this field has been stopped because of the risks already mentioned [107].

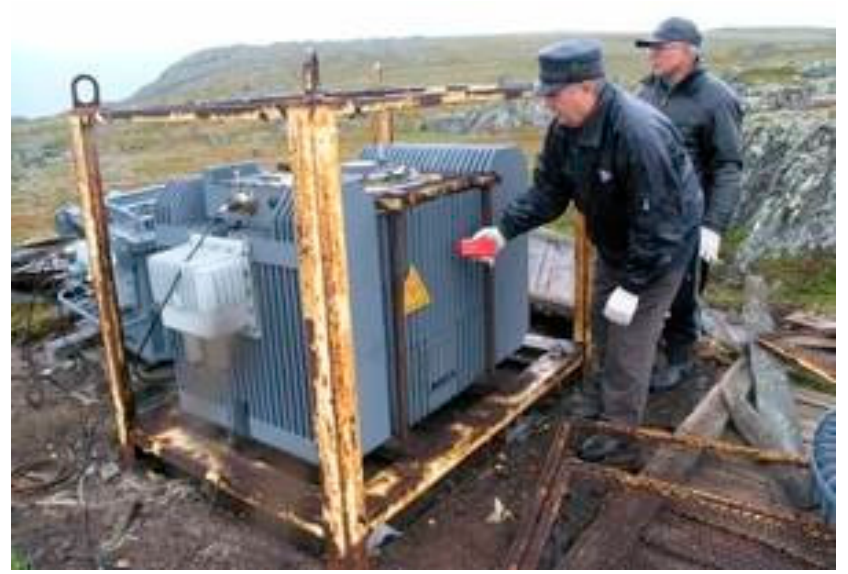

Figure 6. Radioisotope Thermoelectric Generator (RTG) used to supply power to lighthouses and navigation beacons [106].

\subsubsection{Medical Domain}

In 1966, small plutonium cells (very small RTGs fed with Pu238) were used in implanted pacemakers to ensure a very long battery life, as shown in Figure 7 [108]. In 2004, about 90 of them were still in use. Many companies have manufactured nuclear-powered pacemakers, including ARCO (Perma-grain), Medtronic (Laurens-Alcatel), Gulf General Atomic, Cordis (Telektronic, Accuffix), American Optical, Technologie Biocontrol (Coratomic) and Medical Devices, Inc (MDI) [109]. After the development of lithium batteries, the market for nuclear batteries dried up [110].
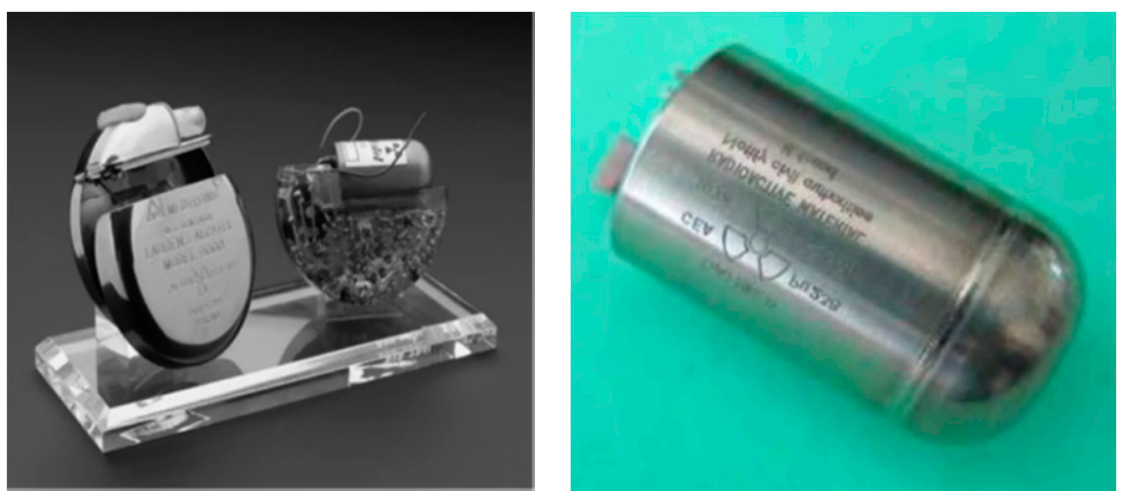

Figure 7. Left pacemaker and right RTG battery [108]. 


\subsection{Natural Heat Source}

\subsubsection{Natural Gas and Biomass}

Pouillet, in 1840, employed the Seebeck effect in making a thermoelectric cell with a welded pair of bismuth and copper. The two solderings were immersed in two vessels, one containing melting ice and the other hot water [111]. This apparatus supplying a constant source of dynamic electricity was used by the author to investigate the general laws of currents [112].

At the same time several prototypes of thermoelectric batteries were built and even commercialized, with different sizes and materials for different purposes [113]. For instance, the Oersted and Fourier battery they designed for their investigations [114], the Ruhmkorff Thermopile (1860) powered by gas and cooled with water [115], and the gigantic Clamond battery (1879), which was the first thermoelectric battery powered with coal or wood, and which could have been used in industry, with a height of $2.50 \mathrm{~m}$ and $1 \mathrm{~m}$ in diameter. Its maximum power was 192 Watts, at 54 Volts and 3.5 Amperes [116]. It is worthy of note that the most remarkable achievement was Melloni's Thermo-Multiplier, built in 1830, which was an instrument for making very small amounts of sensitive heat. The battery consisted of about 10 Bismuth-antimony pairs that were associated with a Nobili galvanometer. This instrument was so sensitive that the galvanometer needle was deflected by the presence of the natural heat of a person placed $10 \mathrm{~m}$ from the battery [117].

Nowadays, thermopiles or TEG thermoelectric generators are designed to supply energy to autonomous sensors, installed in remote locations subject to severe environmental conditions, i.e., very low-temperature and difficult-to-access locations, where conventional renewable energy sources, such as solar and wind energy, are not regularly available. Heat is usually supplied by a flameless catalytic burner [118]. A few manufactures of thermoelectric generators powered by natural gas are installed in more than 55 countries. For instance, Gentherm manufactures TEGs with powers ranging from 15 to $550 \mathrm{~W}$. These generators are mainly used on offshore platforms, along pipelines, at high altitudes or near gas wells (Figure 8) [119]. Another example is Farwest Corrosion Control, a company that manufactures and installs TEGs for cathodic protection against pipe corrosion, and that has installed more than 15,000 generators in 51 countries [120].

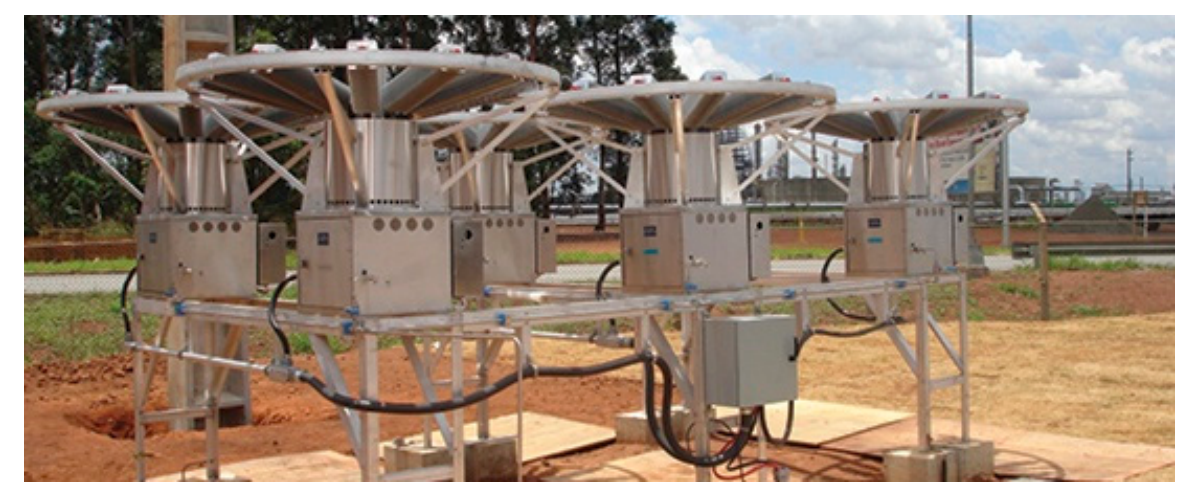

Figure 8. Gentherm Gas TEG [119].

Several products designed for public use have been marketed. One such was the thermoelectric candle radio (1990), which uses the heat from candles to power a radio via a $\mathrm{FeSi}_{2}$ TE module [121]. These applications have become obsolete with the emergence of other more practical technologies, but despite that, more specific applications are still emerging, such as the CampStove shown in Figure 9. This appliance, designed for camping in general, burns wood to produce $2 \mathrm{~W}$ of $0.4 \mathrm{~A}$ and $5 \mathrm{~V}$ power using a thermoelectric generator to which the connection of the electrical devices is made via a USB port [122]. 


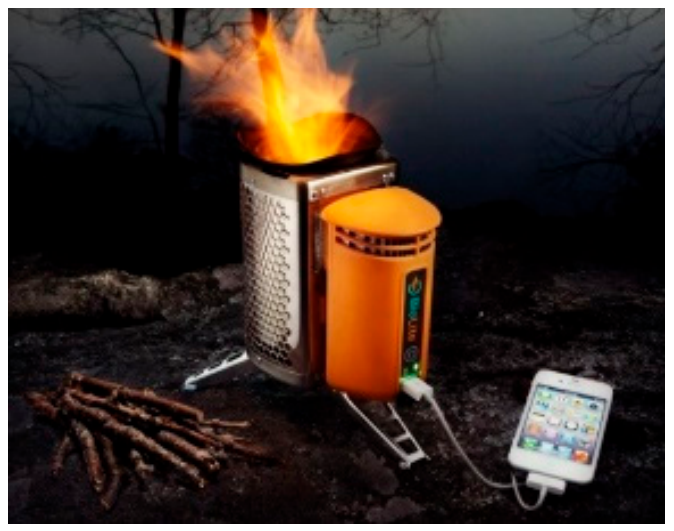

Figure 9. Picture of a CampStove [122].

\subsubsection{Human Body}

As the heat of the human body is natural and stable, it could be used to supply some electricity in very specific applications, such as medical ones [123,124]. The human body releases around $100 \mathrm{~W}$ of heat at rest, and $525 \mathrm{~W}$ during physical effort [125].

Several investigations have been conducted into wearable thermoelectric generators (WTEGs) since 2001 [126], with the aim of substituting lithium-ion batteries [127] as a power source for portable devices, given that the global market for portable technologies is growing rapidly and is expected to exceed USD 34 billion by 2020 and USD 78 billion by 2021 [128]. WTEGs are classified according to their rigid or flexible (extensible or not) [129] architectures in 2D or 3D configurations [130], or according to their TE component materials, which are inorganic, organic or hybrid [131].

Leonov and Vullers [124] published an interesting review on WTEGs, focusing on rigid- and flexible-type thermoelectric generators. They concluded that the wearable thermoelectric generator style was mature, and that the major concern was to improve the efficiency of the generator and make it thinner and more flexible. These authors conducted extensive research on rigid substrate TEGs. They developed different WTEG products that used body heat, such as the wireless electrocardiography system integrated into an office shirt. This product was powered by 17 small TE modules integrated into the front side of a shirt, as shown in Figure 10. They converted the body's natural heat flow into 0.8-3 $\mathrm{mW}$ of electrical energy, depending on the physical activity of the person [132].

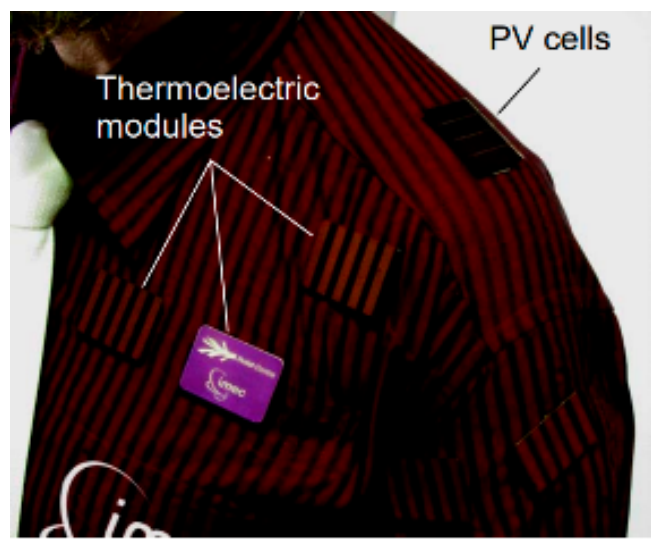

Figure 10. Wearable Thermoelectric Generator (WTEG) integrated into a shirt [132].

One of the leading companies in this field is IMEC (Belgium), which has been working on thermoelectric generation by people since the 2000s, with a view to power electronic health care systems. IMEC and the Holst Centre have developed several wireless sensors, such as the Body-powered Electroencephalogram Acquisition System, which produces $2-2.5 \mathrm{~mW}$ of power and is worn as a 
headband, shown in Figure 11a [133]. They have also developed a wireless pulse oximeter (2006), powered entirely by a TEG-style watch using commercial $\mathrm{Bi}_{2} \mathrm{Te}_{3}$ thermopiles, shown in Figure $11 \mathrm{~b}$, and in which the generator develops around $89 \mu \mathrm{W}$ of power [134].

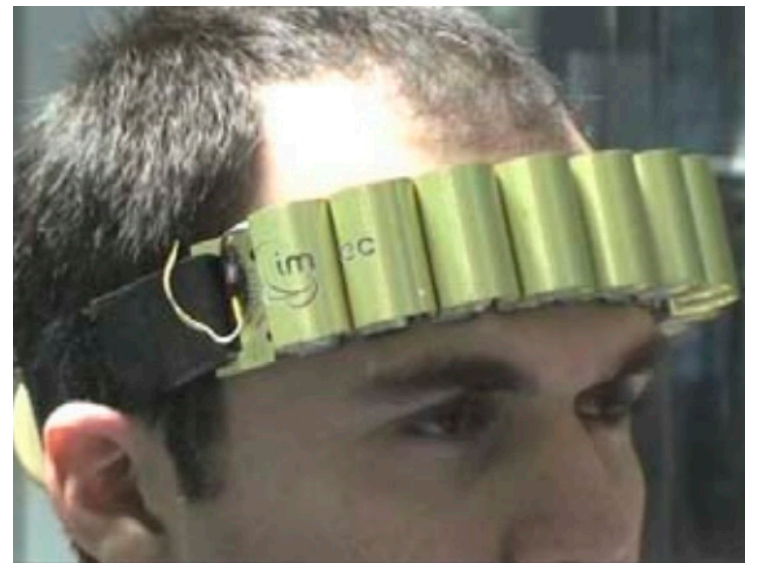

(a)

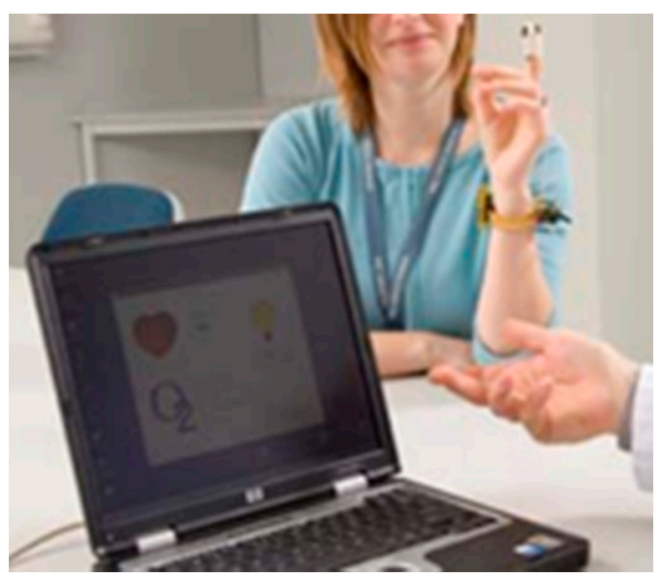

(b)

Figure 11. (a) TEG supplies power to an EEG system mounted on an expandable headband [133]; (b) Wireless pulse oximeter [134].

The first thermoelectric wristwatch powered by converting body heat into electrical power was marketed by Seiko and Citizen, and dates back to 1999 [135,136]. The Seiko watch (Figure 12a) produced $22 \mu \mathrm{W}$ of electrical power, and an open-circuit voltage of $300 \mathrm{mV}$ with efficiency of about $0.1 \%$ [137]. Another example is the Dyson TE bracelet (2012), shown in Figure 12b, which, using body heat, charged a battery integrated into it for charging a mobile phone or any other mobile device.

Because of the drawbacks of rigid modules, i.e., the high thermal resistance between skin and the TEG, flexible modules are more suitable for power generation from body heat, as they can be adapted to the shape of the body, thus increasing the useful surface area for heat capture and reducing thermal contact resistance [139]. Francioso et al. [123] developed a flexible and wearable micro thermoelectric generator, composed of an array of 100 thin film thermocouples of $\mathrm{Sb}_{2} \mathrm{Te}_{3}$ and $\mathrm{Bi}_{2} \mathrm{Te}_{3}$, designed to power very low-consumption electronical ambient assisted living (AAL) applications. The best result obtained was $430 \mathrm{mV}$ in open circuit, and an electrical output power up to $32 \mathrm{nW}$ at $40{ }^{\circ} \mathrm{C}$. Kim et al. [140] manufactured a flexible fabric-shaped TEG, with 3D printing technology, composed of 20 thermocouples and with a thickness of $0.5 \mathrm{~mm}$, as shown in Figure 13a. The TEG, when applied to a human body, generated an electrical power of $25 \mathrm{mV}$ at an ambient temperature of $5{ }^{\circ} \mathrm{C}$. A new approach was presented by Suarez et al. [141], using standard bulk legs interconnected to a stretchable low-resistivity eutectic alloy of gallium and indium (EGaIn), all in a flexible elastomer package, as 
shown in Figure 13b. The authors reported a figure of merit (ZT) of 0.35 , which they claimed to be better than that of any other similar device reported in the open literature. Zadan et al. [142] introduced a soft and stretchable thermoelectric generator (TEG) with the ability to expand, to explore the integration of this TEG into wearable technologies. All investigations conducted so far have suggested that this option is only viable at moderate temperatures, i.e., indoors in particular, and this limits its application together with the high cost of TE modules [143].
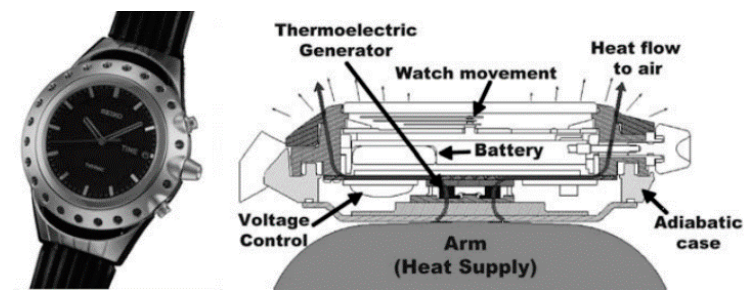

(a)

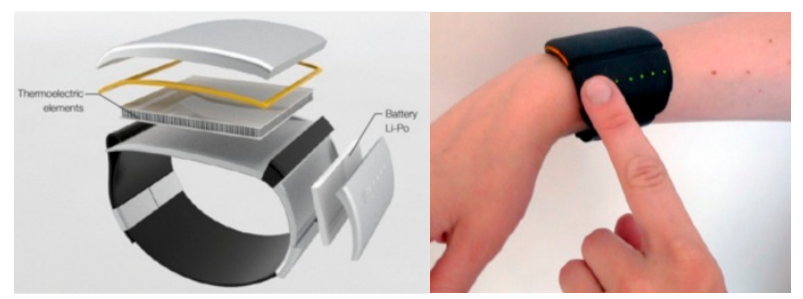

(b)

Figure 12. (a) Seiko Thermic, wristwatch [137]; (b) Dyson bracelet [138].

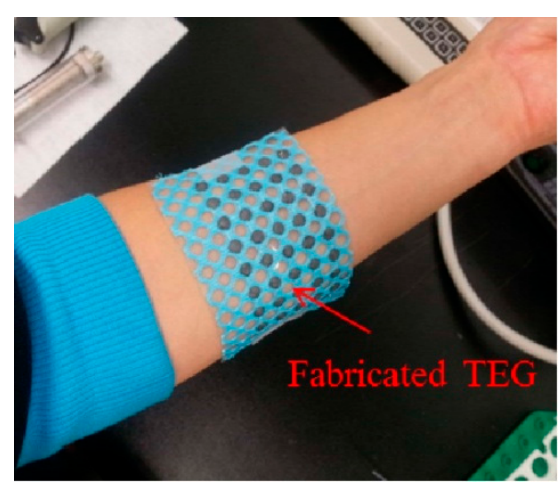

(a)

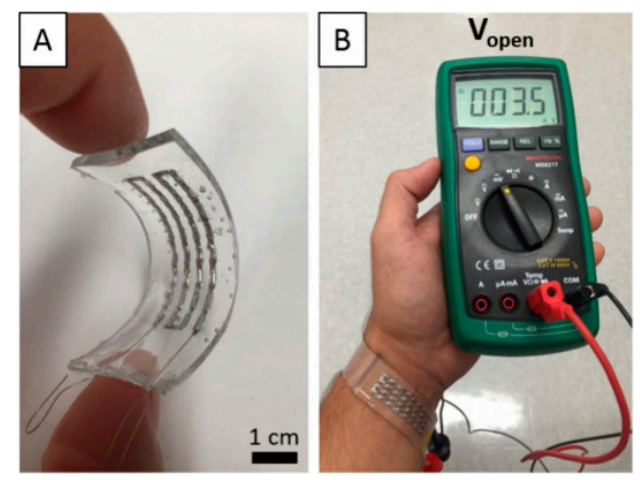

(b)

Figure 13. (a) Flexible TEG fabricated using dispenser printing technology [144]. (b) Flexible device and test configuration: (A) flexible device tested, (B) circuit voltage open at room temperature [141]. 
Soleimani et al. [145] published a review on recent developments in inorganic, organic and hybrid wearable TEGs. The authors concluded that inorganic TE materials remain favorable due to their high ZT $(\sim 1)$, but unfavorable due to their rarity, toxicity and impractical rigidity. Organic TE materials have a high flexibility and contain non-toxic elements, but their weaknesses are their low stability in air and the complexity of their synthesis process. They reported that hybrid TE materials are the solution to the rigidity of inorganic TE materials and the low efficiency of organic TE materials. These hybrid TE materials are suitable for portable TEGs. Jiang et al. [146] presented a review focused on the recent developments of TE materials, concerning film- and fiber-based materials for flexible, wearable applications. They concluded that these applications will eventually become a reality with the development of preparation technology for film or fiber legs, and the emergence of human thermoregulatory models for the designing of wearable devices and their integration with other wearable renewable energy conversion devices.

\subsubsection{Sun Source}

A solar thermoelectric generator (STEG) is a system designed to recover heat from solar radiation and convert it into electricity using a thermoelectric generator (TEG). It is becoming a technological alternative, and is competing with the dominant solar photovoltaic systems despite its low conversion efficiency compared to photovoltaic technology [147]. STEGs are classified according to the type of optical sensors used, namely, an optical concentration system or not. Optical concentration sensors are usually cylindrical lenses, Fresnel lenses, parabolic mirrors, flat mirrors or parabolic concentrators. Non-concentrated solutions are rather limited to flat plate collectors evacuated or not evacuated, and vacuum tubes [148]. Karthick et al. [149], in a recent review, reported that the use of optical concentrators, combined with heat pipe tubes, improves the efficiency of solar thermoelectric generators (STEG).

The first investigation into thermoelectric solar energy dates back to the end of the 19th century, with Weston's patent in 1888 [150,151], which combined a thermopile (TEG), with a mirror or lens to focus solar radiation on hot junctions, and a storage battery. In 1910, Sun Electric Generator Company [152] published claims concerning the functioning of a thermoelectric solar generator. The first experimental data on an STEG device were published by Coblentz in 1922 [153], describing an efficiency of less than $0.01 \%$. More progress was reported in 1954 concerning a STEG device designed by Telkes [154], who demonstrated an efficiency of the optical concentrators in a flat-plate solar energy collector of $0.63 \%$ and $3.35 \%$, at $1 \times$ and $50 \times$ suns $\left(1 \mathrm{sun}=1000 \mathrm{~W} / \mathrm{m}^{2}\right)$, respectively. ZnSb-type alloys in combination with a negative Bi-alloy were used. The most significant investigations into solar thermoelectric generators (STEGs) are summarized in the following. He et al. [155] carried out a theoretical and experimental study on the integration of thermoelectric modules into solar vacuum tube heaters (SHP-TE), as illustrated in Figure 14. Their experimental data showed an electrical efficiency of $1 \%$, which is slightly lower than a system with an organic Rankine cycle, but according to the authors the SHP-TE system is simple and has no moving components, and its units are easy to replace. Following the same principle, another creative investigation was done with the use of a parabolic solar concentrator $[156,157]$.

Kraemer et al. [158] used nanostructured thermoelectric materials to develop the solar flat panel thermoelectric generators shown in Figure 15. These TEs achieved a maximum efficiency of $4.6 \%$ under an irradiation of $1 \mathrm{~kW} / \mathrm{m}^{-2}$. The efficiency was seven to eight times higher than the best value previously reported for a flat panel display.

Amatya and Ram [159] combined a commercial $\mathrm{Bi}_{2} \mathrm{Te}_{3}$ module with a parabolic concentrator (solar concentration of $66 \mathrm{x}$ suns. A system efficiency of $3 \%$ was measured and an output power of $1.8 \mathrm{~W}$ was achieved. Rehman et al. [160] proposed a novel collector design for a solar concentrated thermoelectric generator. The system had an electrical efficiency of $1.45 \%$ and a maximum optical efficiency of $93.61 \%$. $\mathrm{Li}$ et al. [161] evaluated a prototype, consisting of a solar concentration thermoelectric generator (CTG) with a Fresnel lens (Figure 16). Their results showed that the highest possible CTG efficiency 
could reach $9.8 \%, 13.5 \%$ and $14.1 \%$, for $\mathrm{Bi}_{2} \mathrm{Te}_{3}$, skutterudite and silver antimony lead telluride (LAST) alloys, respectively.

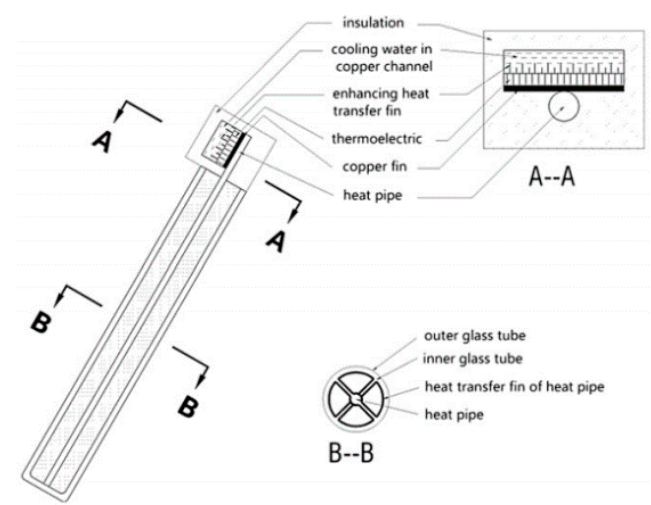

Figure 14. Schematic diagram of an integrated Solar Heat-Pipe/Thermoelectric (SHP-TE) system [155].

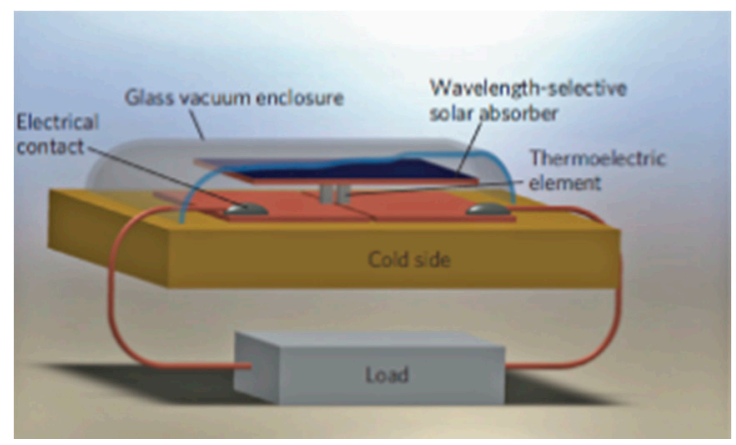

Figure 15. Illustration of a STEG cell consisting of a pair of thermoelectric elements type p and n [158].

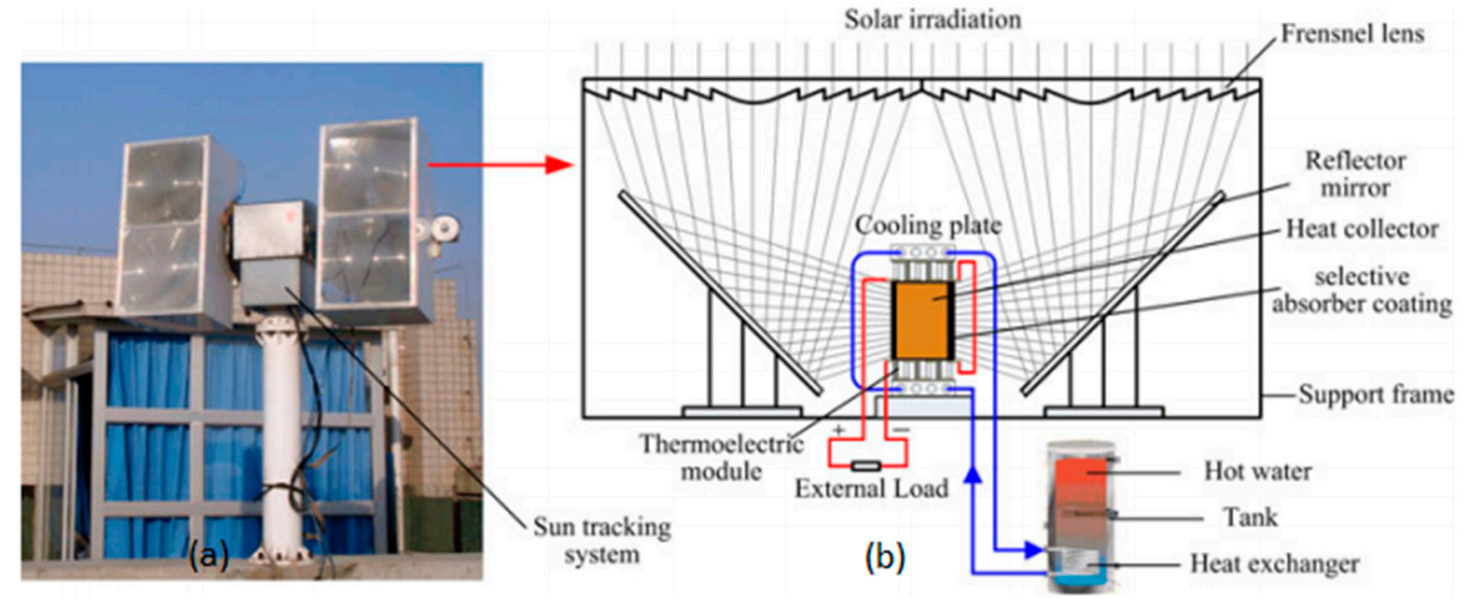

Figure 16. Concentrating Solar Thermoelectric Generators (CTG): (a) An experimental prototype of the Concentrating Solar Thermoelectric Generator System; (b) Details of the CTG unit [149].

Photovoltaic and thermoelectric systems are the only processes that directly convert solar energy into electrical energy $[162,163]$. Some investigations were conducted on hybrid photovoltaic-thermoelectric systems [164] and concentrated photovoltaic (CPV)-thermoelectric systems [165]. Another hybrid system consists of the direct coupling of a solar water heater with a thermoelectric module, in order to improve the overall performance of the system producing heat and electricity simultaneously [166]. However, their combination is complex because of their opposing characteristics, and effective integration of the two systems is essential [167]. Sripadmanabhan Indira et al. [168] investigated different configurations of the hybrid system integrating photovoltaic concentrators (CPV) and thermoelectric generators 
(TEG), and outlined recommendations for future research. The authors reported that the integrated CPV-TEG-based solar thermal systems achieve higher electrical and thermal performances than those of non-concentrated PV-TEG systems. Li et al. [169] compared a hybrid photovoltaic-thermoelectric (PV-TE) system employing a micro-channel heat pipe array together with PV electricity generation. The results showed that the electrical efficiencies of the hybrid PV-TE system were about $14 \%$ higher than those obtained with the PV system.

Mizoshiri et al. [170] built a hybrid module composed of a thin-film thermoelectric module and a photovoltaic module. This hybrid module filtered light through an infrared filter (hot mirror), allowing only the light that contributed to photovoltaic conversion to pass through. At the same time, the reflected light was focused on the warm side of the thermoelectric module using a lens. The total no-load voltage of the hybrid thermo-photovoltaic generator showed an increase of $1.3 \%$ when compared with the photovoltaic module alone. As regards TPV/TE hybrid systems, thermophotovoltaic cells (TPV) are capable of converting infrared radiation into electricity. They consist of a heat source, an emitter, a filter and photovoltaic (PV) cells [171]. Unlike photovoltaic solar panels, TPV cells are illuminated by radiant combustion sources. Given that the radiant power density of these sources can be much higher than that of the sun, the electrical power density of TPV cells is much higher than that of solar cells, with an efficiency of 24.5\% [172]. As of yet, few studies have been conducted on integrated TPV/TE systems. Qiu and Hayden [173] reported that the efficiency of an integrated system with TPV GaSb cells and TEG was superior to that of individual TPV and TE. For this reason, the TPV/TE hybrid system is an interesting alternative system, and further research is required in the future [174]. The major concern with hybrid systems is to achieve optimal hybridization. This means ensuring that the sum of the maximum powers produced separately by the PV and TE systems equals the power produced by the hybrid system [175].

\subsection{Waste Heat Source}

A huge amount of low-grade waste heat is released into the environment, without any attempt at heat recovery [43]. Over the last three decades, much effort has been made to improve the efficiency of thermoelectric technology used in heat recovery applications [176]. This is facilitated by the fact that TE technology could be easily adapted to the physical parameters, such as the temperature, pressure, and heat transfer fluid, of a given heat recovery application. Waste heat recovery using thermoelectric technology can be divided into two main groups, as follows.

\subsubsection{Waste Heat Recovery from Industry and Homes}

Dai et al. [177] reported that, in United States, 33\% of industrial manufacturing energy is released directly into the atmosphere or into cooling systems as waste heat, and this amount of heat could be used to produce 0.9 TWh to 2.8 TWh of electricity per year, if thermoelectric materials with average ZT values ranging from 1 to 2 were available. Hence, there is a need for technical and economic studies that will develop the feasibility of large-scale applications that, in the medium and long term, would make this a competitive source of clean energy [178]. Zou et al. [179] demonstrated that municipal wastewater can be used to produce electricity using a thermoelectric generator (TEG). Their theoretical study, performed for the Christiansburg Wastewater Treatment Plant, estimated energy generation of 1094 to $70,986 \mathrm{kWh}$ per year, with a saving of USD 163 to USD 6076. In another investigation that used an air-cooling heat recovery device with $120-\mathrm{mm}$ square pipes, the wastewater recovery efficiency was $1.28 \%$, and the amortization period for the equipment extended to 8 years [180].

Araiz et al. [181] carried out a techno-economic study into the thermoelectric recovery of hot gases from a stone wool manufacturing plant. They reported a maximum net power production of $45 \mathrm{~kW}$, and a Levelized Cost of Electricity at about $0.15 \mathrm{EUR} / \mathrm{kWh}$, which demonstrated the feasibility of the system. Mirhosseini et al. [182] performed a similar investigation, using an arc-shaped absorber designed for the thermoelectric heat recovery of waste heat from a rotary cement kiln. The economic evaluation showed that the dominant parameter in the system cost is the heat sink. 
It is worth noting that heat recovery depends strongly on the ambient temperature. In hot regions, investigations were mainly focused on the recovery of heat released from air conditioning systems [183]. However, investigations into heat recovery were more diversified in cold regions. Killander and Bass [184] developed and tested a prototype of a thermoelectric generator designed to supply small amounts of electricity using heat from existing wood stoves in homes in the cold and isolated regions of northern Sweden. The cost of connection to the grid in this region ranged from USD 5000 to USD 120,000 per house. The device provided sufficient energy for electric lighting and watching television during the long winter nights. In the Netherlands, Gasunie Research, an energy network operator developed in 1999-2000, built and tested 20 autonomous (self-powered) boilers that used the heater flame produced to co-generate enough electricity to operate its electrical components, using six Hz-20 thermoelectric modules [185]. They concluded that these thermoelectric generators supplied $60 \mathrm{~W}$ of electricity, which was enough to run their electrical components. Other tests were carried out in the United States of America and England [186], on residential-scale hydronic central heating units that were modified with the addition of a thermoelectric production stage, to demonstrate autonomous operation in a realistic environment. The thermoelectric stage is a set of 18 thermoelectric modules made of bismuth telluride alloy, which generates an electrical power of $109 \mathrm{~W}$, sufficient to supply the blower, the gas control and the water pump of the hydronic central heating. According to Sornek et al. [187], the commercial success of such an installation has to be focused on: (i) introduction of necessary modifications to the heating devices, and (ii) the development of a dedicated structure of the TEG.

In the case of operating conditions in which ambient temperature is not as important as the arrangement of the system off-grid, Bass and Farley [188] tested three thermoelectric generators designed to provide electrical energy in a natural gas field. These generators converted the waste heat produced by the equipment used in the gas field into a thermal energy source for the generators. Electricity was used for cathodic protection, telemetry power supply and lighting. Further, the US military used thermoelectric technology to reduce the logistics of field feeding by integrating thermoelectric devices into the Assault Kitchen that was used to heat food rations out on the field. These devices had no need for an external electrical generator to power the Assault Kitchen. In addition, they produced an excess of electricity that could be used for lighting, battery charging, radio power, communication equipment, etc. [189].

\subsubsection{Waste Heat Recovery from Transport Systems}

\section{Automobiles}

Road transport in Europe contributes about $20 \%$ of the total carbon dioxide emissions, $75 \%$ of which come from private cars, and similar rates are observed in America and Asia [190]. European regulations aim to achieve a $\mathrm{CO}_{2}$ emissions target of $95 \mathrm{~g} / \mathrm{km}$ by 2021, and $68 \mathrm{~g} / \mathrm{km}$ by 2025 , for passenger cars and light commercial vehicles [191]. It is worth taking into account that two thirds of a vehicle's combustion energy is lost as waste heat, $40 \%$ of which is in the form of hot exhaust gas [192,193]. If about $6 \%$ of exhaust heat could be converted to electrical energy, it would be possible to reduce fuel consumption by about $10 \%$ [194].

To this end, the major American, Asian and European automobile companies, in collaboration with research institutes and universities, are trying to develop various types of TEGs to improve the fuel economy of their vehicle models, to preserve and gain an additional share in the future automobile market, which will undoubtedly be more restrictive. Agudelo et al. [195] tested a diesel passenger car in a climatic chamber in order to determine the potential for energy recovery from exhaust gases. They concluded that the potential fuel savings ranged from $8 \%$ to $19 \%$, and the silencer showed the highest energy losses, so the installation of a TEG needed to be located prior to it. Moreover, there are three main possible locations for the TEG [190], namely: (i) The TEG is placed at the end of the exhaust system; (ii) The TEG is located between the catalytic converter and the silencer-the best 
option; and (iii) The TEG is located upstream of the catalytic converter and silencer. If the weight of the installed TEG and the additional pressure drops in the exhaust system are not optimized, the vehicle will consume more fuel than it needs to save, and consequently the system becomes totally inefficient [196]. The different thermoelectric generators manufactured for automobiles (ATEG) can be compared depending on the shape, material or suitable heat transfer system.

In the late 1980s, Birkholt [197], in collaboration with Porsche, proposed a thermoelectric generator with a rectangular cross-section, which was able to produce up to $58 \mathrm{~W}$ under peak conditions with $\mathrm{FeSi}_{2}$ elements. At the end of the 1990s, the Nissan Research Center from Japan [198] developed a TE generator with a rectangular cross-section of 72 modules. Each one of these modules contained eight pairs of Si-Ge elements to be applied in gasoline-powered vehicles. The electrical power supplied by the generator was $35.6 \mathrm{~W}$. Later, they tested a thermoelectric generator composed of $16 \mathrm{Bi}_{2} \mathrm{Te}_{3}$ modules operating at low temperature; the electrical power generated by the generator was $193 \mathrm{~W}$ [199]. In 1992, Hi-Z Technology started the development of a 1-kW thermoelectric generator for diesel truck engines with funding from the U.S. Department of Energy and the California Energy Commission [200]. Amerigon (now Gentherm) developed thermoelectric generators for passenger vehicles between 2004 and 2011, in five phases. The project was sponsored by the US Department of Energy (DOE), and counted on the participation of BMW and Ford in phase 3, and Faurecia in phase 5. [201]. Phases 1 and 2 dealt with the tests of a low-temperature liquid/liquid TEG, which developed $500 \mathrm{~W}$ and was built with $\mathrm{Bi}_{2} \mathrm{Te}_{3}$ materials implanted in a flat plate TEG design [201,202]. In phase 3, a two stage flat plate-shaped gas/liquid TEG at a high temperature (above $600^{\circ} \mathrm{C}$ ), consisting of TE elements segmented in two stages and based on a half-Heusler alloy ( $\mathrm{Zr}, \mathrm{Hf}$ ), was installed near the hot gas inlet and $\mathrm{Bi}_{2} \mathrm{Te}_{3}$ elements near the outlet. The measured output power was about $100 \mathrm{~W}[201,203]$. During phases 4 and 5, a new cylindrical design was selected due to the limitations encountered with the flat plate design, and the power output reached over $200 \mathrm{~W}$ in phase 4 . In the final phase, power output improvement was achieved with a BMW X6 (Figure 17) and a Lincoln MKT (Ford), with more than $600 \mathrm{~W}$ produced in vehicle tests and more than $700 \mathrm{~W}$ in bench tests $[201,204,205]$. This success led Gentherm, BMW and Tenneco in 2011 to launch a new program, projected over seven years, using a new thermoelectric cartridge device. The electricity generated by the TEG could save fuel consumption by $2 \%$, which was far from the program's aims. General Motors developed a prototype using Bi-Te and Skutterudite modules, which was installed on a Chevrolet suburban [206]. The skutterudites used at high temperatures were their final choice. Average power developed by the TEG was expected to be $350 \mathrm{~W}$ for city driving cycles, and $600 \mathrm{~W}$ on motorways [207]. In 2013, Fiat and Chrysler announced the manufacture of the first light commercial vehicle equipped with a TEG [208] with a fuel economy of $4 \%$. The TEG used cross-flow architecture, with segmented TE elements of TAGS, $\mathrm{Bi}_{2} \mathrm{Te}_{3}-\mathrm{PTe}$ and Skutterudites. Another relevant development was called RENOTER [209], an association between Renault and Volvo involving eight partners, partially financed by the French government. This project was carried out with the aim of installing thermoelectric generators (the TEGs) in their car range.

Bou Nader [211] proposed an innovative thermodynamic configuration, and investigated the fuel-saving potential of hybrid electric vehicles using a thermoelectric generator system as an energy converter, instead of the conventional internal combustion engine. Simulation results revealed a $33 \%$ higher fuel consumption with the chosen thermoelectric generator configuration, compared to the conventional internal combustion engine. This investigation highlighted the importance of increasing the thermoelectric generator module's figure of merit in order to achieve a system efficiency comparable to the internal combustion engine. This energy converter has the potential for implementation in future powertrains with zero carbon alternative fuels. Recently, Shen et al. [210] presented the current status, challenges and future prospects of automotive exhaust thermoelectric generators. The authors cited 11 challenges to overcome before the possibility of commercial applications could be realized. These are mainly the low efficiency of the TEG, insufficient heat extraction capacity and non-uniform temperature distribution on the exhaust side, and the space limitation. 


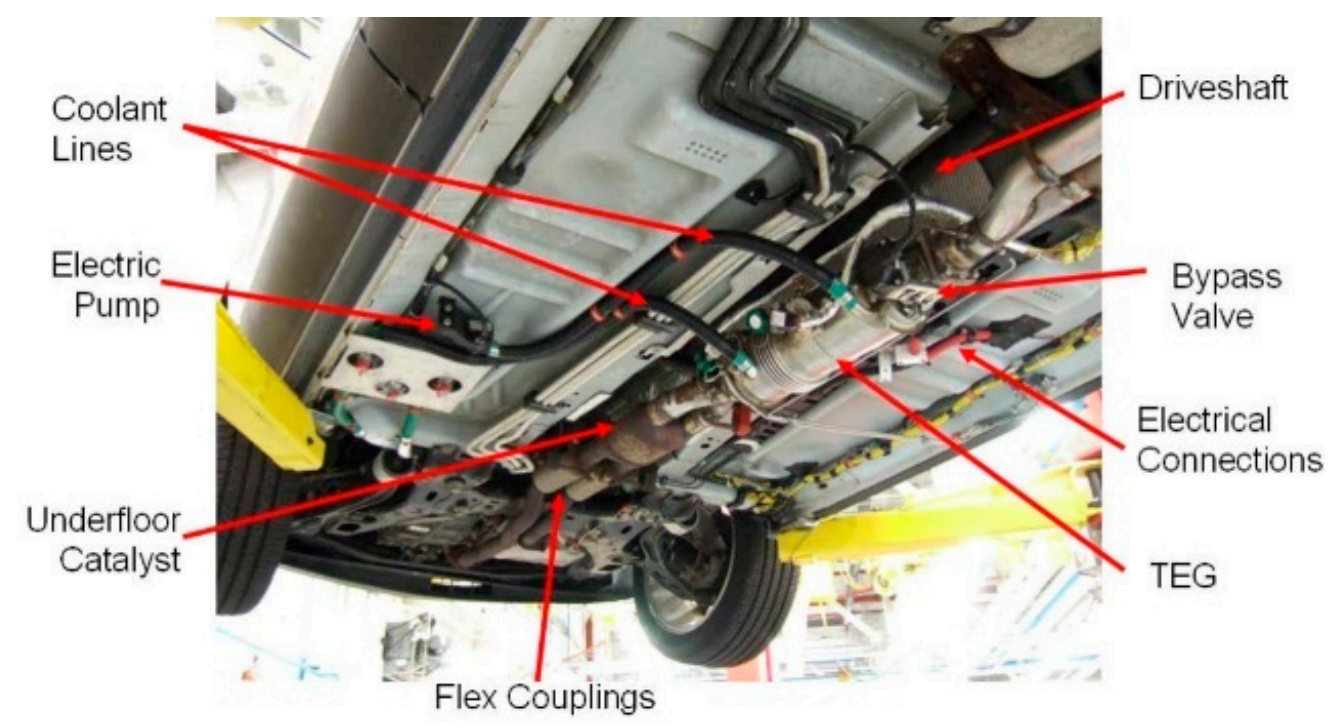

Figure 17. TEG integration into the exhaust line of the BMW X6 prototype vehicle [210].

Motorcycles

Motorcycles are the most commonly used means of transport in some countries, such as Indonesia. Septiadi et al. [212] investigated the usefulness of installing a thermoelectric generator on the exhaust of a motorcycle. Their results showed that the output voltage reached was $15.7 \mathrm{~V}$ and $7.7 \mathrm{~V}$, for TEGs of four modules and two modules, respectively. In 2013, ATSUMITEC, in cooperation with the Nagoya Institute of Technology, applied the Heusler module to the underpower generator of a motorcycle [213], by integrating the thermoelectric device with a fuel cell, as illustrated in Figure 18. The fuel cell produced energy from trace quantities of spent fuel in the exhaust gases. The temperature difference between heat from the exhaust gases and heat generated by the chemical reaction in the fuel cell was used to generate power by means of the thermoelectric device. The total output power of the fuel cell plus the thermoelectric power was $400 \mathrm{~W}$ [214]. Schlichting et al. [215] tested the feasibility of installing a TEG on a motorcycle, with the aim of replacing the alternator with a TEG unit. They used 570 modules to match the alternator output. They concluded that the potential of replacing the alternator with TEG units was quite low.
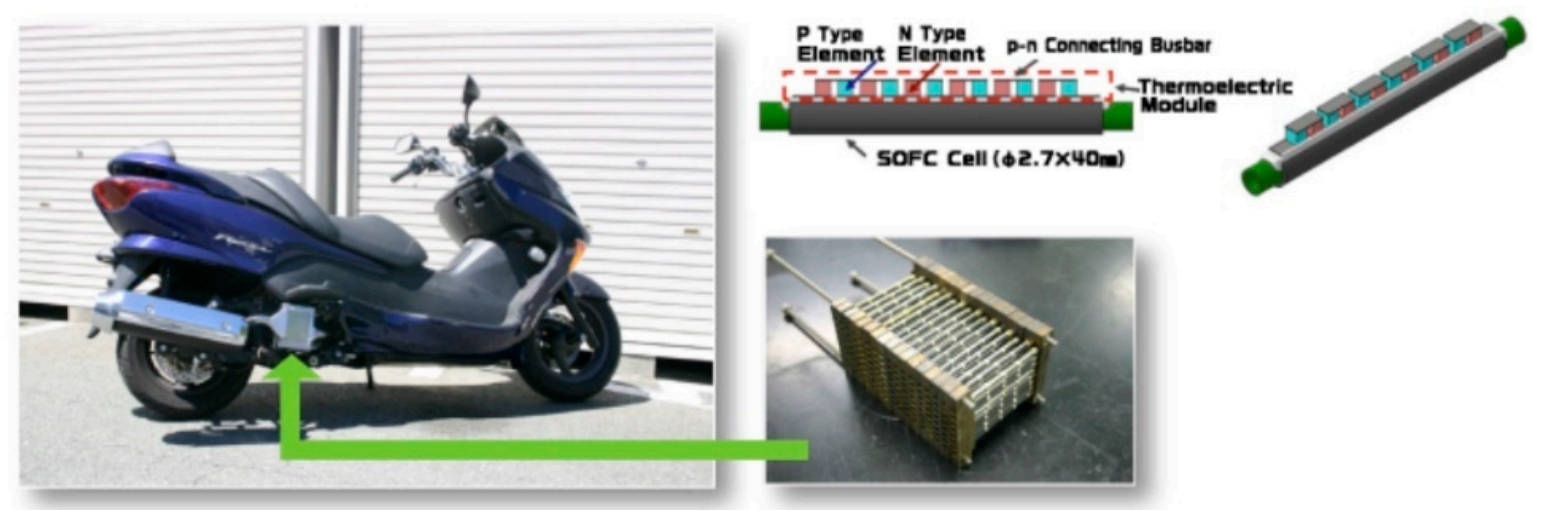

Figure 18. TEG installed in the exhaust gases of a motorcycle [213].

Aircraft

Modern aircrafts are increasingly equipped with sensors and transmitters for better control and monitoring, and greater safety. The supply of power to these sensors via power lines would result in additional heavy wiring, causing additional fuel consumption. The use of thermoelectric generators to 
power such instruments is one of the most promising approaches. The implementation of autonomous wireless sensor networks would lead to a reduction in aircraft weight and complexity, thus reducing fuel consumption.

Boeing Research \& Technology estimated that a $0.5 \%$ reduction in fuel consumption would be translated into a USD 12.075 million reduction in monthly operating costs for U.S. commercial aircrafts, and approximately a $0.03 \%$ reduction in carbon emissions for U.S. passenger aircrafts, taking into account the fact that aircrafts' contribution to global carbon emissions is approximately 2\% [216]. A recent study carried out in the framework of the German Aeronautical Research Program (LuFo-5) on the performance of a thermoelectric generator, integrated between the hot part of a propeller and the bypass flow of the cooler, demonstrated that the efficiency of the TEG ranged from 3\% to 7\%, with a power of $1 \mathrm{~kW} / \mathrm{m}^{2}$ to $9 \mathrm{~kW} / \mathrm{m}^{2}$ depending on its location in the various hot parts of the propeller [217]. Lyras et al. [218] designed a TEG to be installed between the inside and outside walls of the aircraft, since the fuselage is exposed to extremely low temperatures $\left(\sim-50{ }^{\circ} \mathrm{C}\right)$ [219], while the inside of the aircraft has a controlled temperature $\left(\sim+20{ }^{\circ} \mathrm{C}\right)$ for passenger comfort. Some sensors, such as the stress sensor [220], which controls the state of health of the hull, must be installed on different parts of the aircraft. Therefore, it would be very useful to be able to employ a TEG attached directly to the fuselage and combined with a phase-change material (PCM) heat storage unit. This would create a temperature gradient during takeoff and landing, which could generate electricity to power a node of autonomous low-power wireless sensors [221,222]. The system was successfully integrated and functionally tested, qualifying it for use in a flight test facility [220].

Helicopters have also been considered, through a study on the feasibility of recovering helicopter exhaust gases using thermoelectric modules. The results of this study showed that the electrical energy produced under real operating conditions was significant, but currently insufficient, particularly if we take into account the weight/power ratio [223].

Ships

There is scarce research reported regarding the thermoelectric recovery of lost heat from ships in the open literature. Maritime shipping alone represents about 2.8\% of greenhouse gases in the world [224]. Moreover, the integration of thermoelectric power generation into ships is more advantageous than integration into other transportation systems, because cooling water is fully available. The integration of thermoelectricity in this sector is almost inexistent because of the absence of strict international regulations imposing permissible pollution rates for ships, unlike the automotive sector. The European Union is currently planning measures to reduce emissions from international maritime transport [22], so the introduction of new and stricter rules should increase the rate of research.

A project called ECOMARINE, co-financed by the European Union (European Social Fund) and Greek national funds, was carried out to implement a thermoelectric energy recovery unit, with the aim of maximizing electricity production by waste heat recovery, and simultaneously improving the quality of electrical energy. In this context, Loupis et al. [225] developed a tubular TEG with a diameter of $500 \mathrm{~mm}$, which ensured a very low pressure drop of the exhaust gas flows during their passage through the RTG. The authors reported a conversion efficiency of $6.4 \%$, a waste heat recovery of $1.2 \%$, and an electricity supply of $20.3 \mathrm{~kW}$.

\section{History of International Conferences on Thermoelectric}

The first International Conference on the Conversion of Thermoelectric Energy (ICOTEC) was held in 1976, and afterwards every two years until 1988 at the University of Texas at Arlington. In 1988, the European Conference on Thermoelectricity and the International Conference on the Conversion of Thermoelectric Energy were merged, and called the International Conference on Thermoelectricity (ICT). Since then, this conference has been organized every two years in Europe and the United States of America. At the ICT1990 conference held in Pasadena, California, Charles Wood was nominated as the first president of the International Thermal Electricity Society (ITS), and placed in charge of the 
coordination of thermoelectricity activities worldwide. In 1993, the ICT conference was organized in Japan, and a three-year rotation is taking place between the United States, Europe and Asia [226].

The European Thermoelectric Society (ETS) is a non-profit scientific association, founded in 1995 as a regional organization of the International Thermoelectric Society (ITS). It organizes the annual European Conference on Thermoelectricity (ECT). The 19th ECT and 40th ICT will be held in Krákow, Poland in 2021. Details about the previous conferences and workshops can be found on the ETS web page in reference [227-230].

\section{Conclusions}

The special nature of using thermoelectric generators, to supply an electric current with a temperature difference of any small value and over a wide temperature range, has made them the core solution to certain energy problems regarding power generation and heat recovery in a static and non-polluting way, even under extreme environmental conditions. The low efficiency of this conversion technology has limited its development, except in certain sectors where the advantages of TEGs are more favorable over other technologies. The use of thermoelectricity in various laboratory and industrial sectors has resulted in there being different perspectives. It has achieved significant success in some applications and total failure in others. The current investigations into thermoelectric generators are focused on the development of new efficient thermoelectric materials to overcome the drawbacks of the interconnected electrical and thermal properties of these materials, and new designs of thermoelectric generators that allow better integration into energy conversion systems, from the point of view of efficiency and the environmental impact. Interest in this technology has been revived with the appearance of nanotechnology, which has made it possible to cross the historical barrier of $\mathrm{ZT}<1$, resulting in an exponential increase in publications in this field.

In this review, the state-of-the-art of thermoelectric generators, applications and recent progress are all reported. Fundamental knowledge of the thermoelectric effect, basic laws, and parameters affecting the efficiency of conventional and new thermoelectric materials, are all discussed. The applications of thermoelectricity are grouped into three main domains. The first group deals with the use of heat emitted from a radioisotope to supply electricity to various devices, with only space proving to be the area in which thermoelectricity was successful. In the second group, a natural heat source can be useful for producing electricity, but this group of thermoelectricity is still at an undeveloped phase because of low conversion efficiency, leaving applications still at laboratory level. The third group is progressing at a high speed, mainly because the investigations are funded by governments and/or car manufacturers whose final aim is to reduce vehicle fuel consumption, and consequently mitigate greenhouse gas emissions.

Author Contributions: Investigation, methodology and writing-original draft preparation, M.A.Z.; conceptualization, supervision and funding acquisition, S.B; conceptualization and supervision, J.G.S.; conceptualization, methodology, writing-review and editing and supervision, M.B. All authors have read and agreed to the published version of the manuscript.

Funding: This research received no external funding.

Acknowledgments: Mohamed Amine Zoui gratefully acknowledges the University of Adrar for funding his internships at Rovira i Virgili University of Tarragona (Spain).

Conflicts of Interest: The authors declare no conflict of interest.

\section{Nomenclature}

$\mathrm{ZT} \quad$ figure of merit

S Seebeck coefficient, $\mu \mathrm{V} / \mathrm{K}^{-1}$

$\sigma \quad$ electrical conductivity, $\mathrm{S} / \mathrm{m}^{-1}$

$\mathrm{K}$ thermal conductivity, $\mathrm{W} / \mathrm{m}^{-1} / \mathrm{K}^{-1}$

$\mathrm{T}$ temperature, $\mathrm{K}$ 


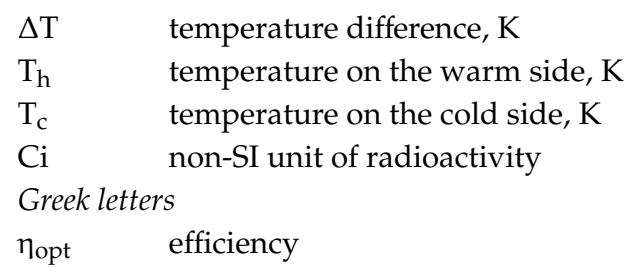

\section{References}

1. Elsheikh, M.H.; Shnawah, D.A.; Sabri, M.F.M.; Said, S.M.; Hassan, M.H.; Bashir, M.B.A.; Mohamad, M. A review on thermoelectric renewable energy: Principle parameters that affect their performance. Renew. Sustain. Energy Rev. 2014, 30, 337-355. [CrossRef]

2. Stoll, B.L.; A SmithiD, T.; Deinert, M. Potential for rooftop photovoltaics in Tokyo to replace nuclear capacity. Environ. Res. Lett. 2013, 8, 014042. [CrossRef]

3. Arutyunov, V.S.; Lisichkin, G.V. Energy resources of the 21st century: Problems and forecasts. Can renewable energy sources replace fossil fuels? Russ. Chem. Rev. 2017, 86, 777-804. [CrossRef]

4. Oral, A.Y.; Oral, Z.B.B. (Eds.) 3rd International Congress on Energy Efficiency and Energy Related Materials (ENEFM2015): Proceedings, Oludeniz, Turkey, 19-23 October 2015; Springer International Publishing: Berlin/Heidelberg, Germany, 2017; Available online: https://www.springer.com/us/book/9783319456768 (accessed on 8 June 2018).

5. Schierning, G.; Chavez, R.; Schmechel, R.; Balke, B.; Rogl, G.; Rogl, P. Concepts for medium-high to high temperature thermoelectric heat-to-electricity conversion: A review of selected materials and basic considerations of module design. Transl. Mater. Res. 2015, 2, 025001. [CrossRef]

6. Ma, T.; Qu, Z.; Yu, X.; Lu, X.; Wang, Q. A review on thermoelectric-hydraulic performance and heat transfer enhancement technologies of thermoelectric power generator system. Therm. Sci. 2018, 22, 1885-1903. [CrossRef]

7. Radousky, H.B.; Liang, H. Energy harvesting: An integrated view of materials, devices and applications. Nanotechnol. 2012, 23, 502001. [CrossRef] [PubMed]

8. Stockholm, J.G. Génération thermoélectrique. Actes Des Journées Electrotechniques Du Club EEA-Energie PorTable 2002.: Autonomie et intégration dans l'environnement Humain, Cachan, France, 21-22 March 2002. Available online: https://www.academia.edu/16362069/DISPOSITIFS_\%C3\%89LECTROM\%C3\% 89CANIQUES_PERMETTANT_L_EXPLOITATION_DE_L_\%C3\%89NERGIE_DES_MOUVEMENTS_ HUMAINS? auto=download (accessed on 9 June 2020).

9. Seebeck, T.J. Magnetische Polarisation der Metalle und Erze durch Temperatur-Differenz; Abhandlungen der Königlichen Preußischen Akademie der Wissenschaften zu Berlin; Verlag von Wilhelm Engelman: 1895. Available online: https://onlinelibrary.wiley.com/doi/abs/10.1002/andp.18260820302 (accessed on 9 June 2020).

10. Peltier, J.C. Nouvelles expériences sur la caloricité des courants électriques. Annales de Chimie et de Physique 1834, 56, 371-386.

11. Thomson, W. On the Dynamical Theory of Heat Transfer. Trans. R. Soc. Edinb. 1851, 3, 91-98.

12. Altenkirch, E. Über den nutzeffekt der thermosäule. Physikalische Zeitschrift 1909, 10, 560.

13. Altenkirch, E. Elektrothermische Kälteerzeugung und reversible elektrische Heizung. Physikalische Zeitschrift 1911, 12, 920-924.

14. Altenkirch, W.W.E.; Gehlhoff, G.R. Thermo-Electric Heating and Cooling Body. U.S. Patent 1120781A, 15 December 1914. Available online: https://patents.google.com/patent/US1120781A/en (accessed on 9 June 2018).

15. Goldsmid, H.J.; Douglas, R.W. The use of semiconductors in thermoelectric refrigeration. Br. J. Appl. Phys. 1954, 5, 386-390. [CrossRef]

16. Bin Masood, K.; Kumar, P.; Singh, R.A.; Singh, J. Odyssey of thermoelectric materials: Foundation of the complex structure. J. Phys. Commun. 2018, 2, 062001. [CrossRef]

17. Ioffe, A.F. Power Application Principles of Semiconductor Thermopiles. USSR Acad. Sci. 1950.

18. BJohn, F.; Harry, B.; Reggie, S. Thermoelectric Cooling Units. U.S. Patent 2932953A, 19 April 1960. Available online: https://patents.google.com/patent/US2932953A/en (accessed on 9 June 2018). 
19. Hicks, L.D.; Dresselhaus, M.S. Effect of quantum-well structures on the thermoelectric figure of merit. Phys. Rev. B 1993, 47, 12727-12731. [CrossRef]

20. Vining, C.B. ZT 3.5: Fifteen years of progress and things to come. In 5th European Conference on Thermoelectrics, ECT2007; Odessa House of Scientists: Odessa, Ukraine, 2007.

21. Roy, C. Manufacture of Thermoelectric Devices. U.S. Patent 2980746A, 18 April 1961. Available online: https://patents.google.com/patent/US2980746A/en\#patentCitations (accessed on 9 June 2018).

22. Champier, D. Thermoelectric Generators: A Review of Present and Future Applications. In Springer Proceedings in Energy; Springer Science and Business Media LLC: Cham, Switzerland, 2016; pp. 203-212.

23. Merkulov, O.V.; Politov, B.V.; Chesnokov, K.Y.; Markov, A.A.; Leonidov, I.A.; Patrakeev, M.V. Fabrication and Testing of a Tubular Thermoelectric Module Based on Oxide Elements. J. Electron. Mater. 2018, 47, 2808-2816. [CrossRef]

24. Jang, H.; Kim, J.B.; Stanley, A.; Lee, S.; Kim, Y.; Park, S.H.; Oh, M.-W. Fabrication of Skutterudite-Based Tubular Thermoelectric Generator. Energies 2020, 13, 1106. [CrossRef]

25. Min, G.; Rowe, D.M. Ring-structured thermoelectric module. Semicond. Sci. Technol. 2007, 22, 880-883. [CrossRef]

26. He, R.; Schierning, G.; Nielsch, K. Thermoelectric Devices: A Review of Devices, Architectures, and Contact Optimization. Adv. Mater. Technol. 2017, 3, 1700256. [CrossRef]

27. Kim, T.Y.; Negash, A.; Cho, G. Direct contact thermoelectric generator (DCTEG): A concept for removing the contact resistance between thermoelectric modules and heat source. Energy Convers. Manag. 2017, 142, $20-27$. [CrossRef]

28. Kim, T.Y.; Negash, A.; Cho, G. Experimental and numerical study of waste heat recovery characteristics of direct contact thermoelectric generator. Energy Convers. Manag. 2017, 140, 273-280. [CrossRef]

29. Qu, W.; Plötner, M.; Fischer, W.-J. Microfabrication of thermoelectric generators on flexible foil substrates as a power source for autonomous microsystems. J. Micromech. Microeng. 2001, 11, 146-152. [CrossRef]

30. Itoigawa, K.; Ueno, H.; Shiozaki, M.; Toriyama, T.; Sugiyama, S. Fabrication of flexible thermopile generator. J. Micromech. Microeng. 2005, 15, S233-S238. [CrossRef]

31. Takashiri, M.; Shirakawa, T.; Miyazaki, K.; Tsukamoto, H. Fabrication and characterization of bismuthtelluride-based alloy thin film thermoelectric generators by flash evaporation method. Sens. Actuators $A$ 2007, 138, 329-334. [CrossRef]

32. Yadav, A.; Pipe, K.P.; Shtein, M. Fiber-based flexible thermoelectric power generator. J. Power Sources 2008, 175, 909-913. [CrossRef]

33. Khan, S.; Dahiya, R.; Lorenzelli, L.; Khan, S. Flexible Thermoelectric Generator Based on Transfer Printed Si Microwires; Institute of Electrical and Electronics Engineers (IEEE): Piscataway, NJ, USA, 2014; pp. 86-89.

34. Lee, H.B.; We, J.H.; Yang, H.J.; Kim, K.; Choi, K.C.; Cho, B.J. Thermoelectric properties of screen-printed ZnSb film. Thin Solid Films 2011, 519, 5441-5443. [CrossRef]

35. Sevilla, G.A.T.; Bin Inayat, S.; Rojas, J.P.; Hussain, M.M.; Hussain, M.M. Flexible and Semi-Transparent Thermoelectric Energy Harvesters from Low Cost Bulk Silicon (100). Small 2013, 9, 3916-3921. [CrossRef]

36. Madan, D.; Wang, Z.; Chen, A.; Wright, P.K.; Evans, J.W. High-Performance Dispenser Printed MA p-Type Bi0.5Sb1.5Te3 Flexible Thermoelectric Generators for Powering Wireless Sensor Networks. ACS Appl. Mater. Interfaces 2013, 5, 11872-11876. [CrossRef]

37. Delaizir, G.; Monnier, J.; Soulier, M.; Grodzki, R.; Villeroy, B.; Testard, J.; Simon, J.; Navone, C.; Godart, C. A new generation of high performance large-scale and flexible thermo-generators based on (Bi,Sb)2 (Te,Se)3 nano-powders using the Spark Plasma Sintering technique. Sens. Actuators A 2012, 174, 115-122. [CrossRef]

38. Fan, P.; Zheng, Z.; Li, Y.-Z.; Lin, Q.-Y.; Luo, J.-T.; Liang, G.-X.; Cai, X.-M.; Zhang, D.-P.; Ye, F. Low-cost flexible thin film thermoelectric generator on zinc based thermoelectric materials. Appl. Phys. Lett. 2015, 106, 73901. [CrossRef]

39. Suemori, K.; Watanabe, Y.; Hoshino, S. Carbon nanotube bundles/polystyrene composites as high-performance flexible thermoelectric materials. Appl. Phys. Lett. 2015, 106, 113902. [CrossRef]

40. Saidur, R.; Rezaei, M.; Muzammil, W.; Hassan, M.; Paria, S.; Hasan, M.H. Technologies to recover exhaust heat from internal combustion engines. Renew. Sustain. Energy Rev. 2012, 16, 5649-5659. [CrossRef]

41. Cramer, C.L.; Wang, H.; Ma, K. Performance of Functionally Graded Thermoelectric Materials and Devices: A Review. J. Electron. Mater. 2018, 47, 5122-5132. [CrossRef] 
42. Jovovic, V.; Kossakovski, D.; Heian, E.M. Thermoelectric Devices with Interface Materials and Methods of Manufacturing the Same. U.S. Patent 9865794B2, 9 January 2018. Available online: https://patents.google. com/patent/US9865794B2/en (accessed on 13 October 2018).

43. Ohta, H.; Sugiura, K.; Koumoto, K. Recent Progress in Oxide Thermoelectric Materials: P-Type Ca3Co4O9and n-Type SrTiO3-. Inorg. Chem. 2008, 47, 8429-8436. [CrossRef]

44. Zide, J.M.; Vashaee, D.; Bian, Z.X.; Zeng, G.; Bowers, J.E.; Shakouri, A.; Gossard, A.C. Demonstration of electron filtering to increase the Seebeck coefficient in In0.53Ga0.47As? In0.53Ga0.28A10.19As superlattices. Phys. Rev. B 2006, 74. [CrossRef]

45. Elarusi, A.; Fagehi, H.; Attar, A.; Lee, H. Theoretical Approach to Predict the Performance of Thermoelectric Generator Modules. J. Electron. Mater. 2016, 46, 872-881. [CrossRef]

46. Buist, R.J. Design and engineering of thermoelectric cooling devices. In Proceedings of the 10th International Conference on Thermoelectrics, Cardiff, Wales, 10 September 1991.

47. Buist, R. Calculation of Peltier Device Performance. CRC Handb. Thermoelectr. 1995, 143-155.

48. Kumar, S.; Heister, S.D.; Xu, X.; Salvador, J.R. Optimization of Thermoelectric Components for Automobile Waste Heat Recovery Systems. J. Electron. Mater. 2015, 44, 3627-3636. [CrossRef]

49. Lau, P.; Buist, R. Calculation of Thermoelectric Power Generation Performance Using Finite Element Analysis; Institute of Electrical and Electronics Engineers (IEEE): Piscataway, NJ, USA, 2002; pp. 563-566.

50. Angrist, S.W. Direct Energy Conversion; Allyn and Bacon: Boston, MA, USA, 1976.

51. Antonova, E.; Looman, D. Finite Elements for Thermoelectric Device Analysis in ANSYS; Institute of Electrical and Electronics Engineers (IEEE): Piscataway, NJ, USA, 2005; pp. 215-218.

52. Release, A. 9.0 Documentation; ANSYS, Inc.: Canonsburg, PA, USA, 2004.

53. Kim, T.Y.; Kim, J. Assessment of the energy recovery potential of a thermoelectric generator system for passenger vehicles under various drive cycles. Energy 2018, 143, 363-371. [CrossRef]

54. Chen, M.; Rosendahl, L.A.; Condra, T. A three-dimensional numerical model of thermoelectric generators in fluid power systems. Int. J. Heat Mass Transf. 2011, 54, 345-355. [CrossRef]

55. Hussain, Q.E.; Brigham, D.R.; Maranville, C.W. Thermoelectric Exhaust Heat Recovery for Hybrid Vehicles. SAE Int. J. Engines 2009, 2, 1132-1142. [CrossRef]

56. Zheng, J.-C. Recent advances on thermoelectric materials. Front. Phys. China 2008, 3, 269-279. [CrossRef]

57. Rurali, R.; Yu, C.; Zardo, I. Special issue on thermoelectric properties of nanostructured materials. J. Phys. D 2018, 51, 430301. [CrossRef]

58. Beretta, D.; Neophytou, N.; Hodges, J.M.; Kanatzidis, M.G.; Narducci, D.; Martin-Gonzalez, M.; Beekman, M.; Balke, B.; Cerretti, G.; Tremel, W.; et al. Thermoelectrics: From history, a window to the future. Mater. Sci. Eng. $R$ 2019, 138, 100501. [CrossRef]

59. Sarbu, I.; Dorca, A. A comprehensive review of solar thermoelectric cooling systems. Int. J. Energy Res. 2017, 42, 395-415. [CrossRef]

60. Chen, K.-X.; Li, M.-S.; Mo, D.-C.; Lyu, S.-S. Nanostructural thermoelectric materials and their performance. Front. Energy 2018, 12, 97-108. [CrossRef]

61. Romanjek, K.; Věšín, S.; Aixala, L.; Baffie, T.; Bernard-Granger, G.; Dufourcq, J. High-Performance Silicon-Germanium-Based Thermoelectric Modules for Gas Exhaust Energy Scavenging. J. Electron. Mater. 2015, 44, 2192-2202. [CrossRef]

62. Vining, C.B. The Thermoelectric Limit ZT 1: Fact or Artifact. In Proceedings of the XIth International Conference on Thermoelectrics; University of Texas: Melville, NY, USA; Arlington, TX, USA, 1992; pp. 223-231.

63. Crane, D.T.; Bell, L. Progress Towards Maximizing the Performance of a Thermoelectric Power Generator; Institute of Electrical and Electronics Engineers (IEEE): Piscataway, NJ, USA, 2006; pp. 11-16.

64. Yatim, N.M.; Sallehin, N.Z.I.M.; Suhaimi, S.; Hashim, M.A. A Review of ZT Measurement for Bulk Thermoelectric Material; AIP Publishing: Melville, NY, USA, 2018; Volume 1972, p. 030002.

65. Liu, S.; Wang, J.; Jia, J.; Hu, X.; Liu, S. Synthesis and thermoelectric performance of Li-doped NiO ceramics. Ceram. Int. 2012, 38, 5023-5026. [CrossRef]

66. Rad, M.K.; Rezania, A.; Omid, M.; Rajabipour, A.; Rosendahl, L.A. Study on material properties effect for maximization of thermoelectric power generation. Renew. Energy 2019, 138, 236-242. [CrossRef]

67. Mamur, H.; Bhuiyan, M.R.A.; Korkmaz, F.; Nil, M. A review on bismuth telluride (Bi2Te3) nanostructure for thermoelectric applications. Renew. Sustain. Energy Rev. 2018, 82, 4159-4169. [CrossRef] 
68. Dughaish, Z. Lead telluride as a thermoelectric material for thermoelectric power generation. Phys. B 2002, 322, 205-223. [CrossRef]

69. LaLonde, A.D.; Pei, Y.; Wang, H.; Snyder, G.J. Lead telluride alloy thermoelectrics. Mater. Today 2011, 14, 526-532. [CrossRef]

70. Gayner, C.; Kar, K.K. Recent advances in thermoelectric materials. Prog. Mater. Sci. 2016, 83, 330-382. [CrossRef]

71. Sootsman, J.R.; Chung, D.Y.; Kanatzidis, M.G. New and Old Concepts in Thermoelectric Materials. Angew. Chem. Int. Ed. 2009, 48, 8616-8639. [CrossRef] [PubMed]

72. Delime-Codrin, K.; Omprakash, M.; Ghodke, S.; Sobota, R.; Adachi, M.; Kiyama, M.; Matsuura, T.; Yamamoto, Y.; Matsunami, M.; Takeuchi, T. Large figure of merit ZT $=1.88$ at $873 \mathrm{~K}$ achieved with nanostructured Si0.55Ge0.35(P0.10Fe0.01). Appl. Phys. Express 2019, 12, 045507. [CrossRef]

73. Anno, H.; Yamada, H.; Nakabayashi, T.; Hokazono, M.; Shirataki, R. Gallium composition dependence of crystallographic and thermoelectric properties in polycrystalline type-I Ba8GaxSi46-x (nominal x=14-18) clathrates prepared by combining arc melting and spark plasma sintering methods. J. Solid State Chem. 2012, 193, 94-104. [CrossRef]

74. Wan, C.; Wang, Y.; Wang, N.; Koumoto, K. Low-Thermal-Conductivity (MS)1+x(TiS2)2 (M = Pb, Bi, Sn) Misfit Layer Compounds for Bulk Thermoelectric Materials. Materials 2010, 3, 2606-2617. [CrossRef]

75. Iversen, B.B.; Palmqvist, A.; Cox, D.E.; Nolas, G.S.; Stucky, G.D.; Blake, N.P.; Metiu, H. Why are Clathrates Good Candidates for Thermoelectric Materials? J. Solid State Chem. 2000, 149, 455-458. [CrossRef]

76. Zou, M.; Li, J.; Kita, T. Thermoelectric properties of fine-grained FeVSb half-Heusler alloys tuned to p-type by substituting vanadium with titanium. J. Solid State Chem. 2013, 198, 125-130. [CrossRef]

77. Yu, J.; Xia, K.; Zhao, X.B.; Zhu, T. High performance p-type half-Heusler thermoelectric materials. J. Phys. D 2018, 51, 113001. [CrossRef]

78. Gascoin, F.; Ottensmann, S.; Stark, D.; Haile, S.M.; Snyder, G.J. Zintl Phases as Thermoelectric Materials: Tuned Transport Properties of the Compounds CaxYb1-xZn2Sb2. Adv. Funct. Mater. 2005, 15, 1860-1864. [CrossRef]

79. Shuai, J.; Mao, J.; Song, S.; Zhang, Q.; Chen, G.; Ren, Z. Recent progress and future challenges on thermoelectric Zintl materials. Mater. Today Phys. 2017, 1, 74-95. [CrossRef]

80. Ferreira, N.; Rasekh, S.; Costa, F.M.; Madre, M.; Sotelo, A.; Diez, J.; Torres, M. New method to improve the grain alignment and performance of thermoelectric ceramics. Mater. Lett. 2012, 83, 144-147. [CrossRef]

81. Wang, Y.F.; Lee, K.H.; Ohta, H.; Koumoto, K. Fabrication and thermoelectric properties of heavily rare-earth metal-doped $\mathrm{SrO}(\mathrm{SrTiO}) \mathrm{n}(\mathrm{n}=1,2)$ ceramics. Ceram. Int. 2008, 34, 849-852. [CrossRef]

82. Lu, D.; Chen, G.; Pei, J.; Yang, X.; Xian, H. Effect of erbium substitution on thermoelectric properties of complex oxide Ca3Co2O6 at high temperatures. J. Rare Earths 2008, 26, 168-172. [CrossRef]

83. Gayner, C.; Kar, K.K.; Wang, H. Recent progress and futuristic development of PbSe thermoelectric materials and devices. Mater. Today Energy 2018, 9, 359-376. [CrossRef]

84. Zhao, L.-D.; Chang, C.; Tan, G.; Kanatzidis, M.G. SnSe: A remarkable new thermoelectric material. Energy Environ. Sci. 2016, 9, 3044-3060. [CrossRef]

85. Li, S.; Li, X.; Ren, Z.; Zhang, Q. Recent progress towards high performance of tin chalcogenide thermoelectric materials. J. Mater. Chem. A 2018, 6, 2432-2448. [CrossRef]

86. Tsai, T.-C.; Chang, H.-C.; Chen, C.-H.; Whang, W.-T. Widely variable Seebeck coefficient and enhanced thermoelectric power of PEDOT:PSS films by blending thermal decomposable ammonium formate. Org. Electron. 2011, 12, 2159-2164. [CrossRef]

87. Choi, Y.; Kim, Y.; Park, S.-G.; Kim, Y.-G.; Sung, B.J.; Jang, S.-Y.; Wang, H. Effect of the carbon nanotube type on the thermoelectric properties of CNT/Nafion nanocomposites. Org. Electron. 2011, 12, 2120-2125. [CrossRef]

88. Yue, R.; Xu, J. Poly(3,4-ethylenedioxythiophene) as promising organic thermoelectric materials: A mini-review. Synth. Met. 2012, 162, 912-917. [CrossRef]

89. McGrail, B.T.; Sehirlioglu, A.; Pentzer, E. Polymer Composites for Thermoelectric Applications. Angew. Chem. Int. Ed. 2014, 54, 1710-1723. [CrossRef]

90. Yemata, T.A.; Ye, Q.; Zhou, H.; Kyaw, A.K.; Chin, W.S.; Xu, J. Conducting polymer-based thermoelectric composites. Hybrid Polym. Compos. Mater. 2017, 169-195. [CrossRef]

91. Duan, W.; Liu, J.; Zhang, C.; Ma, Z. The magneto-thermoelectric effect of graphene with intra-valley scattering. Chin. Phys. B 2018, 27, 097204. [CrossRef] 
92. Olaya, D.; Tseng, C.-C.; Chang, W.-H.; Hsieh, W.; Li, L.-J.; Juang, Z.-Y.; Hernández, Y. Cross-plane thermoelectric figure of merit in graphene-C60 heterostructures at room temperature. FlatChem 2019, 14, 100089. [CrossRef]

93. Deng, S.; Cai, X.; Zhang, Y.; Li, L. Enhanced thermoelectric performance of twisted bilayer graphene nanoribbons junction. Carbon 2019, 145, 622-628. [CrossRef]

94. Selvan, K.V.; Hasan, N.; Ali, M.S.M. State-of-the-Art Reviews and Analyses of Emerging Research Findings and Achievements of Thermoelectric Materials over the Past Years. J. Electron. Mater. 2018, 48, 745-777. [CrossRef]

95. Yang, J.; Caillat, T. Thermoelectric Materials for Space and Automotive Power Generation. MRS Bull. 2006, 31, 224-229. [CrossRef]

96. Jordan, K.; Birden, J. Thermal Batteries Using Polonium-210. (Information Report); Mound Lab.: Miamisburg, OH, USA, 1954.

97. Cataldo, R.L.; Bennett, G.L. US space radioisotope power systems and applications: Past, present and future. In Radioisotopes-Applications in Physical Sciences; InTech: Rijeka, Croatia, 2011.

98. Cataldo, R. Spacecraft Power System Considerations for the Far Reaches of the Solar System. In Outer Solar System; Springer Science and Business Media LLC: Cham, Switzerland, 2018; pp. 767-790.

99. Cataldo, R.L.B. U.S. Space Radioisotope Power Systems and Applications: Past, Present and Future. 2011. Available online: https://ntrs.nasa.gov/search.jsp?R=20120000731 (accessed on 18 June 2018).

100. Kramer, D.P.; Ambrosi, R.; Sarsfield, M.; Watkinson, E.J.; Mesalam, R.; Williams, H.; Barklay, C.; Tinsley, T.; Goodrich, S.; Pierson, T.; et al. Recent Joint Studies Related to the Development of Space Radioisotope Power Systems. E3S Web Conf. 2017, 16, 5002. [CrossRef]

101. Woerner, D. A Progress Report on the eMMRTG. J. Electron. Mater. 2015, 45, 1278-1283. [CrossRef]

102. Holgate, T.; Bennett, R.; Hammel, T.; Caillat, T.; Keyser, S.; Sievers, B. Increasing the Efficiency of the Multi-mission Radioisotope Thermoelectric Generator. J. Electron. Mater. 2014, 44, 1814-1821. [CrossRef]

103. Jaziri, N.; Boughamoura, A.; Müller, J.; Mezghani, B.; Tounsi, F.; Ismail, M. A comprehensive review of Thermoelectric Generators: Technologies and common applications. Energy Rep. 2019. [CrossRef]

104. Arctic Submarine Lab History. Available online: https://web.archive.org/web/20130218182628/http://www. csp.navy.mil/asl/Timeline.htm (accessed on 19 November 2019).

105. Ruffio, J. What Future for Radioisotope Thermoelectric Generators (RTG)? Physics 2017.

106. Radioisotope Thermoelectric Generators, Bellona.Org. 2005. Available online: http://bellona.org/news/ nuclear-issues/radioactive-waste-and-spent-nuclear-fuel/2005-04-radioisotope-thermoelectric-generators-2 (accessed on 14 June 2018).

107. Standring, W.J.F.; Dowdall, M.; Sneve, M.; Selnæs, Ø.G.; Amundsen, I. Environmental, health and safety assessment of decommissioning radioisotope thermoelectric generators (RTGs) in northwest Russia. J. Radiol. Prot. 2007, 27, 321-331. [CrossRef]

108. Prutchi, D. Nuclear Pacemaker-s. 2005. Available online: http://www.prutchi.com/pdf/implantable/nuclear_ pacemakers.pdf (accessed on 9 June 2019).

109. Facts about Pacemakers. Available online: http://osrp.lanl.gov/pacemakers.shtml (accessed on 14 June 2018).

110. Prelas, M.; Boraas, M.; Aguilar, F.D.L.T.; Seelig, J.-D.; Tchouaso, M.T.; Wisniewski, D. Potential ApplicationsPotential Applications for Nuclear Batteries; Springer Science and Business Media LLC: Cham, Switzerland, 2016; Volume 56, pp. 285-305.

111. Cnam, Cnam-Culture-Claude Servais Pouillet, Culture. Available online: http://culture.cnam.fr/made-incnam/claude-servais-pouillet-718304.kjsp?RH=1423328764669 (accessed on 18 June 2018).

112. Gavarret, J. Traité d'électricité; V. Masson: Paris, France, 1807.

113. Strony Internetowe. Available online: http://aztekium.pl/sites.py?tekst=1\&lang=pl (accessed on 18 June 2018).

114. Les Thermocouples-Il y a un Siècle et Plus. Available online: http://aviatechno.net/thermo/thermo_ancien. php?retour=thermo01.php\%23histoire (accessed on 28 September 2018).

115. OBJET Documents 797 sur 935. Available online: http://cugnot.cnam.fr:8000/SEARCH/BASIS/COLLEC/ INTERNET/OBJET/DDW?W\%3DDOM++PH+LIKE+\%27ELECTRICITE/MAGNETISME\%27\%26M\% 3D797\%26K\%3D35493\%26R\%3DY\%26U\%3D1 (accessed on 18 June 2018).

116. Walmsley, R.M. Electricity in the Service of Man: A Popular and Practical Treatise on the Applications of Electricity to Modern Life; Cassell: London, UK; Paris, France; Melbourne, Australia, 1911. 
117. Melloni, M. Mémoire sur la Transmission libre de la Chaleur Rayonnante par Différens Corps Solides et Liquides Présenté à l'Académie des Sciences le 4 feorier 1833 par M; Melloni, Imprimerie de Madame Veuve Thuau: Paris, France, 1833.

118. Bonin, R.; Boero, D.; Chiaberge, M.; Tonoli, A. Design and characterization of small thermoelectric generators for environmental monitoring devices. Energy Convers. Manag. 2013, 73, 340-349. [CrossRef]

119. Thermoelectric Generators (TEGs)|Gentherm Global Power Technologies. Available online: http://www. genthermglobalpower.com/products/thermoelectric-generators-tegs (accessed on 22 June 2018).

120. Thermoelectric Generators for Cathodic Protection by Global Thermoelectric Inc.|Farwest Corrosion Control. Available online: https://www.farwestcorrosion.com/thermoelectric-generators-for-cathodic-protection-byglobal-thermoelectric.html (accessed on 22 June 2018).

121. Horie, S. Thermoelectric Energy Conversion Systems; REALIZE Science \& Engineering: Tokyo, Japan, 1995; pp. 112-115.

122. BioLite-ROW, BioLite Outdoor \& Off-Grid Energy|Rest-Of-World, BioLite-ROW. Available online: https: //row.bioliteenergy.com/ (accessed on 25 June 2018).

123. Francioso, L.; De Pascali, C.; Farella, I.; Martucci, C.; Creti, P.; Siciliano, P.A.; Perrone, A. Flexible thermoelectric generator for ambient assisted living wearable biometric sensors. J. Power Sources 2011, 196, 3239-3243. [CrossRef]

124. Leonov, V.; Vullers, R. Wearable electronics self-powered by using human body heat: The state of the art and the perspective. J. Renew. Sustain. Energy 2009, 1, 62701. [CrossRef]

125. Bhatnagar, V.; Owende, P. Energy harvesting for assistive and mobile applications. Energy Sci. Eng. 2015, 3, 153-173. [CrossRef]

126. Siddique, A.R.M.; Mahmud, S.; Van Heyst, B. A review of the state of the science on wearable thermoelectric power generators (TEGs) and their existing challenges. Renew. Sustain. Energy Rev. 2017, 73, 730-744. [CrossRef]

127. Karthikeyan, V.; Surjadi, J.U.; Wong, J.C.; Kannan, V.; Lam, K.-H.; Chen, X.; Lu, Y.; Roy, V.A.L. Wearable and flexible thin film thermoelectric module for multi-scale energy harvesting. J. Power Sources 2020, 455, 227983. [CrossRef]

128. Nozariasbmarz, A.; Collins, H.; Dsouza, K.; Polash, M.H.; Hosseini, M.; Hyland, M.; Liu, J.; Malhotra, A.; Ortiz, F.M.; Mohaddes, F.; et al. Review of wearable thermoelectric energy harvesting: From body temperature to electronic systems. Appl. Energy 2020, 258, 114069. [CrossRef]

129. Han, S. Wearable Thermoelectric Devices. In Thermoelectric Thin Films; Springer Science and Business Media LLC: Cham, Switzerland, 2019; pp. 31-42.

130. Sun, T.; Zhou, B.; Zheng, Q.; Wang, L.; Jiang, W.; Snyder, G.J. Stretchable fabric generates electric power from woven thermoelectric fibers. Nat. Commun. 2020, 11, 572. [CrossRef] [PubMed]

131. Xu, Q.; Qu, S.; Ming, C.; Qiu, P.; Yao, Q.; Zhu, C.; Wei, T.-R.; He, J.; Shi, X.; Chen, L. Conformal organic-inorganic semiconductor composites for flexible thermoelectrics. Energy Environ. Sci. 2020, 13, 511-518. [CrossRef]

132. Leonov, V.; Torfs, T.; van Hoof, C.; Vullers, R.J. Smart wireless sensors integrated in clothing: An electrocardiography system in a shirt powered using human body heat. Sens. Transducers 2009, 107, 165.

133. van Bavel, M.; Leonov, V.; Yazicioglu, R.F.; Torfs, T.; van Hoof, C.; Posthuma, N.; Vullers, R. Wearable battery-free wireless 2-channel EEG systems powerd by energy scavengers. Sens. Transducers J. 2008, 94, 103-115.

134. Torfs, T. Pulse oximeter fully powered by human body heat. Sens. Transducers J. 2007, 80, 1230-1238.

135. Yuan, Z. Etude et Réalisation de Microgénérateurs Thermoélectriques Planaires en Technologie Silicium. Ph.D. Thesis, Université Lille 1, Lille, France, 2012.

136. Kishi, M.; Nemoto, H.; Hamao, T.; Yamamoto, M.; Sudou, S.; Mandai, M.; Yamamoto, S. Micro thermoelectric modules and their application to wristwatches as an energy source. In Proceedings of the Eighteenth International Conference on Thermoelectrics. Proceedings, ICT'99 (Cat. No.99TH8407), Baltimore, MD, USA, 29 August-2 September 1999; Institute of Electrical and Electronics Engineers (IEEE): Piscataway, NJ, USA, 2003; pp. 301-307.

137. Fernandes, A.E.S.D.S. Conversão de Energia com células de Peltier. Ph.D. Thesis, Faculdade de Ciências e Tecnologia, Caparica, Portugal, 2012. 
138. Dyson Energy Bracelet a Good Call. Available online: https://newatlas.com/dyson-energy-bracelet/12040/ (accessed on 30 September 2018).

139. Suarez, F.; Nozariasbmarz, A.; Vashaee, D.; Öztürk, M.C. Designing thermoelectric generators for self-powered wearable electronics. Energy Environ. Sci. 2016, 9, 2099-2113. [CrossRef]

140. Kim, M.K.; Kim, M.S.; Jo, S.E.; Kim, H.L.; Lee, S.M.; Kim, Y.J. Wearable Thermoelectric Generator for Human Clothing Applications; Institute of Electrical and Electronics Engineers (IEEE): Piscataway, NJ, USA, 2013; pp. 1376-1379.

141. Suarez, F.; Parekh, D.P.; Ladd, C.; Vashaee, D.; Dickey, M.D.; Öztürk, M.C. Flexible thermoelectric generator using bulk legs and liquid metal interconnects for wearable electronics. Appl. Energy 2017, 202, 736-745. [CrossRef]

142. Zadan, M.; Malakooti, M.H.; Majidi, C. Soft and Stretchable Thermoelectric Generators Enabled by Liquid Metal Elastomer Composites. ACS Appl. Mater. Interfaces 2020, 12, 17921-17928. [CrossRef]

143. Geisler, M. Récupération d'énergie Mécanique pour Vêtements Connectés Autonomes. Ph.D. Thesis, Université Grenoble Alpes, Saint-Martin-d'Hères, France, 2017.

144. Cao, Z. Printable Thermoelectric Devices for Energy Harvesting. Ph.D. Thesis, University of Southampton, Southampton, UK, 2014.

145. Soleimani, Z.; Zoras, S.; Ceranic, B.; Shahzad, S.; Cui, Y. A review on recent developments of thermoelectric materials for room-temperature applications. Sustain. Energy Technol. Assess. 2020, 37, 100604. [CrossRef]

146. Li, C.; Jiang, F.; Liu, C.; Liu, P.; Xu, J. Present and future thermoelectric materials toward wearable energy harvesting. Appl. Mater. Today 2019, 15, 543-557. [CrossRef]

147. Zoui, M.A.; Bentouba, S.; Bourouis, M. The Potential of Solar Thermoelectric Generator STEG for Implantation in the Adrar Region. Algerian J. Renew. Energy Sustain. Dev. 2020, 2, 17-27. [CrossRef]

148. Narducci, D.; Bermel, P.; Lorenzi, B.; Wang, N.; Yazawa, K. Solar Thermoelectric Generators; Springer Science and Business Media LLC: Cham, Switzerland, 2018; pp. 45-61.

149. Karthick, K.; Suresh, S.; Hussain, M.M.M.; Ali, H.M.; Kumar, C.S. Evaluation of solar thermal system configurations for thermoelectric generator applications: A critical review. Sol. Energy 2019, 188, 111-142. [CrossRef]

150. Weston, E. Art of Utilizing Solar Radiant Energy. Available online: https://patentimages.storage.googleapis. com/3f/08/67/a6f7bd2416ee1a/US389125.pdf (accessed on 23 June 2020).

151. Weston, E. Apparatus for Utilizing Solar Radiant Energy. Available online: https://patentimages.storage. googleapis.com/1f/55/8f/4f4605a0c953a2/US389124.pdf (accessed on 23 June 2020).

152. View of George Cove's Solar Energy Device | Material Culture Review. Available online: https://journals.lib. unb.ca/index.php/MCR/article/view/17744/22231 (accessed on 1 July 2020).

153. Coblentz, W.W. Harnessing heat from the sun. Sci. Am. 1922, 127.

154. Telkes, M. Solar Thermoelectric Generators. J. Appl. Phys. 1954, 25, 765. [CrossRef]

155. He, W.; Su, Y.; Wang, Y.; Riffat, S.; Ji, J. A study on incorporation of thermoelectric modules with evacuated-tube heat-pipe solar collectors. Renew. Energy 2012, 37, 142-149. [CrossRef]

156. Miljkovic, N.; Wang, E.N. Modeling and optimization of hybrid solar thermoelectric systems with thermosyphons. Sol. Energy 2011, 85, 2843-2855. [CrossRef]

157. Fan, H.; Singh, R.; Akbarzadeh, A. Electric Power Generation from Thermoelectric Cells Using a Solar Dish Concentrator. J. Electron. Mater. 2011, 40, 1311-1320. [CrossRef]

158. Date, A.; Date, A.; Dixon, C.; Akbarzadeh, A. Progress of thermoelectric power generation systems: Prospect for small to medium scale power generation. Renew. Sustain. Energy Rev. 2014, 33, 371-381. [CrossRef]

159. Amatya, R.; Ram, R.J. Solar Thermoelectric Generator for Micropower Applications. J. Electron. Mater. 2010, 39, 1735-1740. [CrossRef]

160. Rehman, N.U.; Uzair, M.; Siddiqui, M.A. Optical analysis of a novel collector design for a solar concentrated thermoelectric generator. Sol. Energy 2018, 167, 116-124. [CrossRef]

161. Li, P.; Cai, L.; Zhai, P.; Tang, X.; Zhang, Q.; Niino, M. Design of a Concentration Solar Thermoelectric Generator. J. Electron. Mater. 2010, 39, 1522-1530. [CrossRef]

162. Sahin, A.Z.; Ismaila, K.G.; Yilbas, B.S.; Al-Sharafi, A. A review on the performance of photovoltaic/ thermoelectric hybrid generators. Int. J. Energy Res. 2020, 44, 3365-3394. [CrossRef]

163. Suleebka, K. High temperature solar thermoelectric generator. Appl. Energy 1979, 5, 53-59. [CrossRef] 
164. Motiei, P.; Yaghoubi, M.; GoshtashbiRad, E.; Vadiee, A. Two-dimensional unsteady state performance analysis of a hybrid photovoltaic-thermoelectric generator. Renew. Energy 2018, 119, 551-565. [CrossRef]

165. Mahmoudinezhad, S.; Rezania, A.; Rosendahl, L.A. Behavior of hybrid concentrated photovoltaic- thermoelectric generator under variable solar radiation. Energy Convers. Manag. 2018, 164, 443-452. [CrossRef]

166. Faddouli, A.; Labrim, H.; Fadili, S.; Habchi, A.; Hartiti, B.; Benaissa, M.; Hajji, M.; Ez-Zahraouy, H.; Ntsoenzok, E.; Benyoussef, A. Numerical analysis and performance investigation of new hybrid system integrating concentrated solar flat plate collector with a thermoelectric generator system. Renew. Energy 2020, 147, 2077-2090. [CrossRef]

167. Shittu, S.; Li, G.; Akhlaghi, Y.G.; Ma, X.; Zhao, X.; Ayodele, E. Advancements in thermoelectric generators for enhanced hybrid photovoltaic system performance. Renew. Sustain. Energy Rev. 2019, 109, 24-54. [CrossRef]

168. Indira, S.S.; Vaithilingam, C.A.; Chong, K.-K.; Saidur, R.; Faizal, M.; Abubakar, S.; Paiman, S. A review on various configurations of hybrid concentrator photovoltaic and thermoelectric generator system. Sol. Energy 2020, 201, 122-148. [CrossRef]

169. Li, G.; Shittu, S.; Zhou, K.; Zhao, X.; Ma, X. Preliminary experiment on a novel photovoltaic-thermoelectric system in summer. Energy 2019, 188, 116041. [CrossRef]

170. Mizoshiri, M.; Mikami, M.; Ozaki, K. Thermal-Photovoltaic Hybrid Solar Generator Using Thin-Film Thermoelectric Modules. Jpn. J. Appl. Phys. 2012, 51, 06FL07. [CrossRef]

171. Ferrari, C.; Melino, F.; Pinelli, M.; Spina, P.; Venturini, M. Overview and Status of Thermophotovoltaic Systems. Energy Procedia 2014, 45, 160-169. [CrossRef]

172. Colangelo, G.; De Risi, A.; Laforgia, D. New approaches to the design of the combustion system for thermophotovoltaic applications. Semicond. Sci. Technol. 2003, 18, S262-S269. [CrossRef]

173. Qiu, K.; Hayden, A. Development of a novel cascading TPV and TE power generation system. Appl. Energy 2012, 91, 304-308. [CrossRef]

174. Huen, P.; Daoud, W.A. Advances in hybrid solar photovoltaic and thermoelectric generators. Renew. Sustain. Energy Rev. 2017, 72, 1295-1302. [CrossRef]

175. Park, K.-T.; Shin, S.-M.; Tazebay, A.S.; Um, H.-D.; Jung, J.-Y.; Jee, S.-W.; Oh, M.-W.; Park, S.-D.; Yoo, B.; $\mathrm{Yu}, \mathrm{C}$; et al. Lossless hybridization between photovoltaic and thermoelectric devices. Sci. Rep. 2013, 3, 2123. [CrossRef] [PubMed]

176. Barma, M.; Riaz, M.; Saidur, R.; Long, B. Estimation of thermoelectric power generation by recovering waste heat from Biomass fired thermal oil heater. Energy Convers. Manag. 2015, 98, 303-313. [CrossRef]

177. Dai, D.; Zhou, Y.; Liu, J. Liquid metal based thermoelectric generation system for waste heat recovery. Renew. Energy 2011, 36, 3530-3536. [CrossRef]

178. Junior, O.H.A.; Calderon, N.H.; De Souza, S.S. Characterization of a Thermoelectric Generator (TEG) System for Waste Heat Recovery. Energies 2018, 11, 1555. [CrossRef]

179. Zou, S.; Kanimba, E.; Diller, T.E.; Tian, Z.; He, Z. Modeling assisted evaluation of direct electricity generation from waste heat of wastewater via a thermoelectric generator. Sci. Total. Environ. 2018, 635, 1215-1224. [CrossRef]

180. Meng, F.; Chen, L.; Xie, Z.; Ge, Y. Thermoelectric generator with air-cooling heat recovery device from wastewater. Therm. Sci. Eng. Prog. 2017, 4, 106-112. [CrossRef]

181. Araiz, M.; Casi, Á.; Catalan, L.; Martínez, Á.; Astrain, D. Prospects of waste-heat recovery from a real industry using thermoelectric generators: Economic and power output analysis. Energy Convers. Manag. 2020, 205, 112376. [CrossRef]

182. Mirhosseini, M.; Rezania, A.; Rosendahl, L.A. Power optimization and economic evaluation of thermoelectric waste heat recovery system around a rotary cement kiln. J. Clean. Prod. 2019, 232, 1321-1334. [CrossRef]

183. Agrawal, R. Development and Analysis of Waste Heat Recovery System by Air Conditioning Application. Int. J. Emerg. Trends Eng. Dev. 2017, 1. [CrossRef]

184. Killander, A.; Bass, J.C. A Stove-Top Generator for Cold Areas; Institute of Electrical and Electronics Engineers (IEEE): Piscataway, NJ, USA, 2002; pp. 390-393.

185. Alien, D.; Mallon, W. Further Development of "Self-Powered Boilers"; Institute of Electrical and Electronics Engineers (IEEE): Piscataway, NJ, USA, 2003; pp. 80-83.

186. Allen, D.T.; Wonsowski, J. Thermoelectric Self-Powered Hydronic Heating Demonstration; Institute of Electrical and Electronics Engineers (IEEE): Piscataway, NJ, USA, 2002; pp. 571-574.

187. Sornek, K.; Filipowicz, M.; Żołądek, M.; Kot, R.; Mikrut, M. Comparative analysis of selected thermoelectric generators operating with wood-fired stove. Energy 2019, 166, 1303-1313. [CrossRef] 
188. Bass, J.; Farley, R. Examples of Power from Waste Heat for Gas Fields; Institute of Electrical and Electronics Engineers (IEEE): Piscataway, NJ, USA, 2002; pp. 547-550.

189. Pickard, D.; DiLeo, F.; Kushch, A.; Hauerbach, M.; LeVine, L. A Self-Powered Field Feeding System; Army Natick Soldier Center MA: Natick, MA, USA, 2006.

190. Fontaras, G.; Zacharof, N.; Ciuffo, B. Fuel consumption and $\mathrm{CO}_{2}$ emissions from passenger cars in Europe-Laboratory versus real-world emissions. Prog. Energy Combust. Sci. 2017, 60, 97-131. [CrossRef]

191. Di Battista, D.; Mauriello, M.; Cipollone, R. Waste heat recovery of an ORC-based power unit in a turbocharged diesel engine propelling a light duty vehicle. Appl. Energy 2015, 152, 109-120. [CrossRef]

192. Yu, C.; Chau, K.T. Thermoelectric automotive waste heat energy recovery using maximum power point tracking. Energy Convers. Manag. 2009, 50, 1506-1512. [CrossRef]

193. Stabler, F. Automotive applications of high efficiency thermoelectrics. In Proceedings of the DARPA/ONR Program Review and DOE High Efficiency Thermoelectric Workshop, San Diego, CA, USA, 24-27 March 2002.

194. Vázquez, J.; Sanz-Bobi, M.A.; Palacios, R.; Arenas, A. State of the art of thermoelectric generators based on heat recovered from the exhaust gases of automobiles. In Proceedings of the 7th European Workshop on Thermoelectrics, Pamplona, Spain, 3-4 October 2002.

195. Agudelo, A.; García-Contreras, R.; Agudelo, J.R.; Armas, O. Potential for exhaust gas energy recovery in a diesel passenger car under European driving cycle. Appl. Energy 2016, 174, 201-212. [CrossRef]

196. Mori, M.; Yamagami, T.; Sorazawa, M.; Miyabe, T.; Takahashi, S.; Haraguchi, T. Simulation of Fuel Economy Effectiveness of Exhaust Heat Recovery System Using Thermoelectric Generator in a Series Hybrid. SAE Int. J. Mater. Manuf. 2011, 4, 1268-1276. [CrossRef]

197. Birkholt, U. Conversion of Waste Exhaust Heat in Automobiles Using FeSi_2 Thermoelements. In Proceedings of the 7th International Conference on Thermoelectric Energy Conversion, Arlington, TX, USA, 16-18 March 1988.

198. Ikoma, K.; Munekiyo, M.; Furuya, K.; Kobayashi, M.; Izumi, T.; Shinohara, K. Thermoelectric Module and Generator for Gasoline Engine Vehicles; Institute of Electrical and Electronics Engineers (IEEE): Piscataway, NJ, USA, 2002; pp. 464-467.

199. Ikoma, K.; Munekiyo, M.; Furuya, K.; Kobayashi, M.; Komatsu, H. Thermoelectric Generator for Gasoline Engine Vehicles Using Bi2Te3 Modules. J. Jpn. Inst. Met. 1999, 63, 1475-1478. [CrossRef]

200. Bass, J.C.; Elsner, N.B.; Leavitt, F.A. Performance of the $1 \mathrm{~kW}$ thermoelectric generator for diesel engines. In Proceedings of the AIP Conference Proceedings; AIP Publishing: Melville, NY, USA, 1994; Volume 316, pp. 295-298.

201. Crane, D.; LaGrandeur, J.; Jovovic, V.; Ranalli, M.; Adldinger, M.; Poliquin, E.; Dean, J.; Kossakovski, D.; Mazar, B.; Maranville, C. TEG On-Vehicle Performance and Model Validation and What It Means for Further TEG Development. J. Electron. Mater. 2012, 42, 1582-1591. [CrossRef]

202. Crane, D.T.; LaGrandeur, J.W.; Harris, F.; Bell, L.E. Performance Results of a High-Power-Density Thermoelectric Generator: Beyond the Couple. J. Electron. Mater. 2009, 38, 1375-1381. [CrossRef]

203. Crane, D.T.; LaGrandeur, J.W. Progress Report on BSST-Led US Department of Energy Automotive Waste Heat Recovery Program. J. Electron. Mater. 2009, 39, 2142-2148. [CrossRef]

204. Bell, L.E.; LaGrandeur, J.W.; Crane, D.T. Progress Report on Vehicular Waste Heat Recovery using a Cylindrical Thermoelectric Generator. Thermoelectr. Goes Automot. 2010, 2, 83-91.

205. Ranalli, M.; Adldinger, M.; Kossakovski, D.; Womann, M. Thermoelectric Generators From Aerospace to Automotive. ATZ Worldw. 2013, 115, 60-65. [CrossRef]

206. Meisner, G.P. Advanced thermoelectric materials and generator technology for automotive waste heat at GM. In Proceedings of the 2nd Thermoelectrics Applications Workshop, San Diego, CA, USA, 3-6 January 2011.

207. Kumar, S.; Heister, S.D.; Xu, X.; Salvador, J.R.; Meisner, G.P. Thermal Design of Thermoelectric Generators for Automobile Waste Heat Recovery. In Volume 1: Heat Transfer in Energy Systems; Theory and Fundamental Research; Aerospace Heat Transfer; Gas Turbine Heat Transfer; Transport Phenomena in Materials Processing and Manufacturing; Heat and; ASME International: New York, NY, USA, 2012; Volume 1, pp. 67-77.

208. Magnetto, D. HeatReCar: First light commercial vehicle equipped with a TEG. In Proceedings of the 3 rd International Conference Thermal Management for EV/HEV, Darmstadt, Germany, 23-26 June 2013.

209. Aixala, L. RENOTER project. In 3rd Thermoelectrics Applications Workshop; US Department of Energy: Baltimore, MD, USA, 2012. 
210. Shen, Z.-G.; Tian, L.-L.; Liu, X. Automotive exhaust thermoelectric generators: Current status, challenges and future prospects. Energy Convers. Manag. 2019, 195, 1138-1173. [CrossRef]

211. Nader, W.B. Thermoelectric generator optimization for hybrid electric vehicles. Appl. Therm. Eng. 2020, $167,114761$. [CrossRef]

212. Septiadi, W.N.; Iswari, G.A.; Rofiq, M.A.; Gitawan, B.; Gugundo, J.M.; Purba, C.A.D. Output voltage characteristic of heat pipe sink thermoelectric generator with exhaust heat utilization of motorcycles. IOP Conf. Ser. 2018, 105, 12129. [CrossRef]

213. Fundamental Research-Atsumitec (Japan). Available online: http://www.atsumitec.co.jp/en/technology/basis (accessed on 13 June 2018).

214. Shinohara, Y. The State of the Art on Thermoelectric Devices in Japan. Mater. Today 2015, 2, 877-885. [CrossRef]

215. Schlichting, A.D.; Anton, S.R.; Inman, D.J. Motorcycle waste heat energy harvesting. In Proceedings of the 15th International Symposium on: Smart Structures and Materials \& Nondestructive Evaluation and Health Monitoring, San Diego, CA, USA, 9-13 March 2008; Volume 6930, p. 69300. [CrossRef]

216. Huang, J. Aerospace and aircraft thermoelectric applications. In Proceedings of the DoE Thermoelectric Applications Workshop, San Diego, CA, USA, 29 September-1 October 2009.

217. Bode, C.; Friedrichs, J.; Somdalen, R.; Köhler, J.; Büchter, K.-D.; Falter, C.; Kling, U.; Ziolkowski, P.; Zabrocki, K.; Müller, E.; et al. Potential of Future Thermoelectric Energy Recuperation for Aviation. J. Eng. Gas Turbines Power 2017, 139, 101201. [CrossRef]

218. Lyras, M.; Zymaride, L.; Kyratsi, T.; Louca, L.; Becker, T. Simulation Based Design of a Thermoelectric Energy Harvesting Device for Aircraft Applications. In Proceedings of the Dynamic Systems and Control Conference. American Society of Mechanical Engineers, Tysons Corner, VA, USA, 11-13 October 2017; p. V003T41A003. [CrossRef]

219. Pidwirny, M. The Layered Atmosphere. Fundam. Phys. Geogr. 2006.

220. Allmen, L.V.; Bailleul, G.; Becker, T.; Decotignie, J.-D.; Kiziroglou, M.E.; Leroux, C.; Mitcheson, P.D.; Muller, J.; Piguet, D.; Toh, T.T.; et al. Aircraft Strain WSN Powered by Heat Storage Harvesting. IEEE Trans. Ind. Electron. 2017, 64, 7284-7292. [CrossRef]

221. Kiziroglou, M.E.; Wright, S.; Toh, T.T.; Mitcheson, P.D.; Becker, T.; Yeatman, E.M. Design and Fabrication of Heat Storage Thermoelectric Harvesting Devices. IEEE Trans. Ind. Electron. 2014, 61, 302-309. [CrossRef]

222. Samson, D.; Otterpohl, T.; Kluge, M.; Schmid, U.; Becker, T. Aircraft-Specific Thermoelectric Generator Module. J. Electron. Mater. 2009, 39, 2092-2095. [CrossRef]

223. Kousksou, T.; Bedecarrats, J.-P.; Champier, D.; Pignolet, P.; Brillet, C. Numerical study of thermoelectric power generation for an helicopter conical nozzle. J. Power Sources 2011, 196, 4026-4032. [CrossRef]

224. Smith, T.W.P.; Jalkanen, J.P.; Anderson, B.A.; Corbett, J.J.; Faber, J.; Hanayama, S.; O'Keeffe, E.; Parker, S.; Johanasson, L.; Aldous, L. Third IMO GHG Study; International Maritime Organization: London, UK, 2015.

225. Loupis, M.; Papanikolaou, N.; Prousalidis, J. Fuel consumption reduction in marine power systems through thermoelectric energy recovery. In Proceedings of the 2nd International MARINELIVE Conference on All Electric Ship, Athens, Greece, 3-5 June 2013; pp. 1-7.

226. Vining, C.; Rowe, D.; Stockholm, J.; Rao, K. History of the International Thermoelectric Society; Informa UK Limited: Colchester, UK, 2005; pp. 1-8.

227. European Thermoelectric Society. Available online: http://www.thermoelectricity.eu/index.html (accessed on 23 June 2020).

228. Hammel, T.; Bennett, R.; Otting, W.; Fanale, S. Multi-Mission Radioisotope Thermoelectric Generator (MMRTG) and Performance Prediction Model; American Institute of Aeronautics and Astronautics (AIAA): Reston, VA, USA, 2009.

229. Priya, S.; Inman, D.J. (Eds.) Energy Harvesting Technologies; Springer Science and Business Media LLC: Boston, MA, USA, 2009.

230. Kraemer, D.; Poudel, B.; Feng, H.-P.; Caylor, J.C.; Yu, B.; Yan, X.; Ma, Y.; Wang, X.; Wang, D.; Muto, A.; et al. High-performance flat-panel solar thermoelectric generators with high thermal concentration. Nat. Mater. 2011, 10, 532-538. [CrossRef] [PubMed]

(C) 2020 by the authors. Licensee MDPI, Basel, Switzerland. This article is an open access article distributed under the terms and conditions of the Creative Commons Attribution (CC BY) license (http://creativecommons.org/licenses/by/4.0/). 